\title{
Assessment of the Canary current upwelling system in a regionally coupled climate model
}

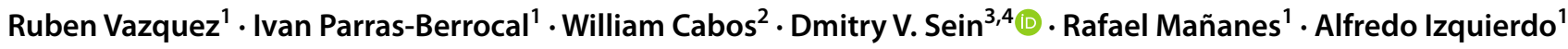

Received: 23 April 2021 / Accepted: 12 July 2021

(c) The Author(s) 2021

\begin{abstract}
The Canary current upwelling is one of the major eastern boundary coastal upwelling systems in the world, bearing a high productive ecosystem and commercially important fisheries. The Canary current upwelling system (CCUS) has a large latitudinal extension, usually divided into upwelling zones with different characteristics. Eddies, filaments and other mesoscale processes are known to have an impact in the upwelling productivity, thus for a proper representation of the CCUS and high horizontal resolution are required. Here we assess the CCUS present climate in the atmosphere-ocean regionally coupled model. The regional coupled model presents a global oceanic component with increased horizontal resolution along the northwestern African coast, and its performance over the CCUS is assessed against relevant reanalysis data sets and compared with an ensemble of global climate models (GCMs) and an ensemble of atmosphere-only regional climate models (RCMs) in order to assess the role of the horizontal resolution. The coupled system reproduces the larger scale pattern of the CCUS and its latitudinal and seasonal variability over the coastal band, improving the GCMs outputs. Moreover, it shows a performance comparable to the ensemble of RCMs in representing the coastal wind stress and near-surface air temperature fields, showing the impact of the higher resolution and coupling for CCUS climate modelling. The model is able of properly reproducing mesoscale structures, being able to simulate the upwelling filaments events off Cape Ghir, which are not well represented in most of GCMs. Our results stress the ability of the regionally coupled model to reproduce the larger scale as well as mesoscale processes over the CCUS, opening the possibility to evaluate the climate change signal there with increased confidence.
\end{abstract}

Keywords Canary current $\cdot$ Coastal upwelling $\cdot$ REMO-OASIS-MPIOM $\cdot$ Climate assessment $\cdot$ Regional climate modelling

Dmitry V. Sein

dmitry.sein@awi.de

1 Department of Applied Physics, Faculty of Marine and Environmental Sciences, Marine Research Institute (INMAR), International Campus of Excellence of the Sea (CEI·MAR), University of Cadiz, Puerto Real, 11510 Cádiz, Spain

2 Departamento de Física y Matemáticas, Universidad de Alcalá, Alcalá de Henares, 28801 Madrid, Spain

3 Alfred Wegener Institute for Polar and Marine Research, 27570 Bremerhaven, Germany

4 Shirshov Institute of Oceanology, Russian Academy of Science, Moscow, Russia 117997

\section{Introduction}

The Eastern Boundary Upwelling Systems (EBUSs) are among the major fishery grounds in the world, contributing more than $20 \%$ to global fish catches, while covering only $2 \%$ of the global ocean surface (Pauly and Christesen 1995). Coastal upwelling systems are generated by the action of the equatorward along-shore winds, which transport coastal surface water offshore, causing the upwelling of the cold and nutrient-rich deep waters by Ekman dynamics. These systems have a large ecological and economic importance (García-Reyes et al. 2015; Varela et al. 2015), hence knowing the response of coastal upwelling to changing climate is of uttermost importance. There are four EBUSs: Canary Current Upwelling System (CCUS), Benguela Current Upwelling System, Humboldt Current Upwelling System and California Current Upwelling System. 
In the EBUSs, the large-scale pressure gradients between are the main drivers of upwelling favourable winds (Bakun 1990; García-Reyes et al. 2015). Bakun (1990) hypothesized that the strengthening of the ocean-land thermal gradient under the greenhouse warming would result in stronger alongshore winds, increasing the upwelling of the deeper water to the surface during the second half of the twentieth century. This hypothesis was supported by Wang et al. (2015), who found a robust relationship between the increase of the land-sea temperature differences and the upwelling intensity in the twenty-first century.

However, Ryckazewski et al. (2015) proposed an alternative hypothesis: changes in the magnitude, timing or location of upwelling winds could be associated with poleward migration and intensification of major atmospheric highpressure cells in response to increased greenhouse gas concentrations. The upwelling systems may be more sensitive to this mechanism than to the increase of the ocean-land thermal gradient (García-Reyes et al. 2015).

Nevertheless, along-shore winds are not the sole driver of change in the EBUSs. Coastal surface warming may increase the water stratification, reducing the upward nutrient-rich transport to surface (Di Lorenzo et al. 2005; García-Reyes et al. 2015; Brady et al. 2019). For instance, Oyarzún and Brierley (2018) showed that the increase of the ocean stratification, as result of global warming, becomes the major mechanism of change during the twenty-first century in the Humboldt Current system. Therefore, the EBUS future behaviour is still uncertain and both stratification and wind changes may be complementary or competitive (Bonino et al. 2019).

In this study we focus on the CCUS, which is part of the North Atlantic subtropical gyre, extending from the northern tip of the Iberian Peninsula at $43^{\circ} \mathrm{N}$ to the south of Senegal at about $10^{\circ} \mathrm{N}$ (Fig. 1a). The coastal upwelling region between Cape Blanc and the Strait of Gibraltar is a yearround phenomenon that becomes stronger to the south of Cape Bojador (Cropper et al. 2014). In the western coast of the Iberian Peninsula $\left(37^{\circ}-43^{\circ} \mathrm{N}\right)$ there is a marked seasonality with along-shore upwelling favourable winds dominating during spring and summer months (Sousa et al. 2017a; Wooster et al. 1976). The Strait of Gibraltar divides both regions, representing a major discontinuity of the upwelling system due to an abrupt change in the coastline orientation in the Gulf of Cádiz (Kämpf and Chapman 2016).

The resolution of the Global Climate Models (GCMs) is insufficient to reproduce mesoscale features or detailed coastal dynamics (Xiu et al. 2018). In fact, recent studies (García-Reyes et al. 2015; Wang et al. 2015; Sein et al. 2017; Gómez-Letona et al. 2017; Bindoff et al. 2019) stressed the need for much higher horizontal resolution for the explicit representation of mesoscale processes that are important for a correct simulation of the upwelling systems but are partly
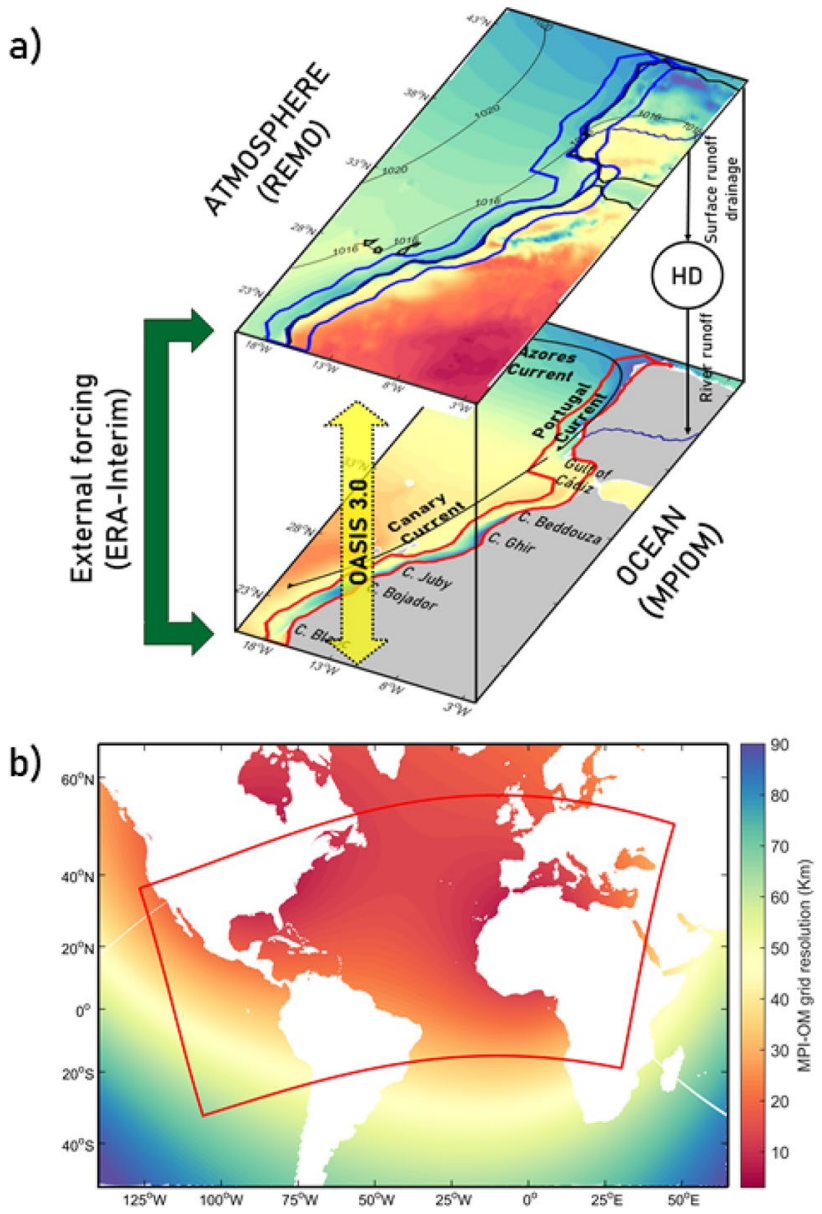

Fig. 1 a ROM coupling scheme, with sea surface temperature (SST) and $2 \mathrm{~m}$ air temperature (T2m). The masks used in SST section (red lines) and to calculate the $\mathrm{T} 2 \mathrm{~m}_{\text {land-sea }}$ differences (blue lines) are overlaid. b MPIOM grid resolution and REMO domain for ROM (red boundary)

masked in the current GCMs. Atmosphere-ocean regional climate models (AORCMs) are able to provide a resolution that allows an explicit representation of these processes and represent a valuable tool for their study.

In this work we use a high-resolution atmosphere-ocean regional coupled model for the study of the CCUS. The main goals of the paper can be summarized as follows:

- First, validating the representation of the inter-annual variability and the seasonal cycle of the CCUS.

- Second, comparing the outputs of regionally coupled model with regional climate models (RCMs) and GCMs to highlight the advantages and disadvantages of the AORCMs in reproducing the CCUS dynamics. 


\section{Data and methods}

ROM (REMO-OASIS-MPIOM; Mikolajewicz et al. 2005; Sein et al. 2015, 2020) is an atmosphere-ocean regional climate model in which the limited area atmospheric model REMO (REgional MOdel; Jacob 2001) is coupled to the global ocean model MPIOM (Max Plank InstituteOcean Model; Marsland et al. 2003; Jungclaus et al. 2013). These components are coupled via the OASIS3.0 (Valcke 2013) coupler. ROM also simulates globally the lateral freshwater fluxes at the land surface through the Hydrological Discharge (HD, Hagemann and Dumenil-Gates $1998,2001)$ model, which is run as part of REMO. Furthermore, the relevant carbon stocks of the atmosphere, the ocean and the sediments are included through the Hamburg Ocean Carbon Cycle (HAMOCC; Maier-Reimer et al. 2005), which is a MPIOM subsystem (Soares et al. 2018, 2019; Parras-Berrocal et al. 2020).

\subsection{ROM configuration}

The atmospheric component of ROM, REMO, is the only model component that is run in a regional configuration. The REMO domain (Fig. 1b) extends to the North Atlantic, the eastern tropical Pacific and the Mediterranean Sea regions, including the whole CCUS region, and has a constant horizontal resolution of $25 \mathrm{~km}$ with a rotated grid (Parras-Berrocal et al. 2020).

MPIOM is discretized on a curvilinear grid with variable spatial resolution ranging from $5 \mathrm{~km}$ at the West African coast to $100 \mathrm{~km}$ in the Southern oceans. In the area of study, the MPIOM resolution is not coarser than $10 \mathrm{~km}$. The MPIOM horizontal resolution in CCUS is sufficiently high to allow for the study of local scale processes in the region while maintaining a global domain with an acceptable computing cost. A similar MPIOM configuration was successfully applied in a process study of the Mediterranean Outflow Waters (Izquierdo and Mikolajewicz 2019). The model has 40 vertical levels with increasing level thickness towards the ocean bottom (Sein et al. 2015; Parras-Berrocal et al. 2020). The spin-up of MPIOM was done according to the procedure described in Sein et al. (2015). MPIOM is started with climatological temperature and salinity data (Levitus et al. 1998). Subsequently, it is integrated six times through the 1958-2002 period forced by ERA-40 and one time by ERA-Interim reanalysis (1979-2012) and with 60 min of the coupling frequency.

In this work, we assess the ROM performance in the CCUS using a simulation forced by ERA-Interim (Dee et al. 2011). ERA-Interim provides lateral boundary conditions to REMO and surface forcing to MPIOM outside the coupling region. Both models are hydrostatic and solve the Navier-Stokes equations using the Boussinesq approximation. In this run HAMOCC was disabled.

\subsection{Assessment strategy and data sets}

The model outputs were assessed in terms of seasonal cycle and inter-annual variability, focusing on the larger scale processes, the latitudinal variability and the mesoscale dynamics that characterizes the CCUS. For the validation, we use daily and monthly data of the most representative atmosphere and ocean variables: near-surface air temperature (T2m), sea surface temperature (SST), wind stress and ocean temperature. This validation is carried out against several observational and reanalysis data sets (Table 1). Additionally, we use the Max Plank Institute-Earth System Model (MPI-ESM), seven RCMs from AFRICA-CORDEX44 (AFR44; Table 2), three RCMs from AFRICA-CORDEX22 (AFR22; Table 3) and four GCMs from CMIP5 (Table 4) to assess ROM performance. The validation strategy addressed:

- Larger scale: The CCUS climate at the larger scale was evaluated by means of OISSTv2 (SST) and ERA5 (wind stress) data. The NOAA $1 / 4^{\circ}$ daily OISST (Reynolds et al. 2007) is an analysis constructed by combining observations from different platforms (satellites, ships, buoys, and Argo floats) on a regular global grid. ERA5 (Copernicus Climate Change Services 2017) is a product of the European Centre for Medium Range Weather Forecast (ECMWF) and covers the Earth on a $30 \mathrm{~km}$ grid and resolves the atmosphere on $137 \mathrm{lev}$ els from the surface up to a height of $80 \mathrm{~km}$. We also used the European Space Agency (ESA) SST Climate Change Initiative (CCI) and C3S global Sea Surface Temperature Reprocessed product (Good et al. 2019),

Table 1 Observational and reanalysis data products selected to assess ROM performance in the CCUS

\begin{tabular}{|c|c|c|c|}
\hline Dataset & Period & Spatial resolution & Reference \\
\hline ERA5 & 1980-2012 & $31 \mathrm{~km}$ & $\begin{array}{l}\text { Copernicus Climate } \\
\text { Change Services } \\
\text { (2017) }\end{array}$ \\
\hline OISST & 1982-2012 & $0.25^{\circ} \times 0.25^{\mathrm{o}}$ & $\begin{array}{l}\text { Reynolds et al. } \\
\text { (2007) }\end{array}$ \\
\hline SODA & 1980-2012 & $0.5^{\circ} \times 0.5^{\mathrm{o}}$ & Carton et al. (2018) \\
\hline WOD18 & 1980-2012 & Not gridded & Boyer et al. (2019) \\
\hline ESA & 1981-2012 & $5 \mathrm{~km}$ & $\begin{array}{l}\text { Merchant et al. } \\
\text { (2019) }\end{array}$ \\
\hline MODIS & 2002 to present & $0.05^{\circ} \times 0.05^{\mathrm{o}}$ & $\begin{array}{l}\text { Hall and Riggs } \\
\text { (2007) }\end{array}$ \\
\hline GLORYS & 1993-2012 & $0.083^{\circ} \times 0.083^{\circ}$ & $\begin{array}{l}\text { Drèvillon et al. } \\
\text { (2018) }\end{array}$ \\
\hline
\end{tabular}


Table 2 AFR44 simulations used to compare ROM with RCMs

\begin{tabular}{lll}
\hline Model & Period & Description \\
\hline RCA4 & $1980-2010$ & Rossby Centre regional atmospheric model (Samuelsson et al. 2015) \\
RACMO22T & $1980-2012$ & Regional atmospheric Climate model version 2.2 (van Meijgaard et al. 2008) \\
CRCM5 & $1980-2012$ & Canadian Regional Climate Model Fifth generation (Takhsha et al. 2017) \\
CCLM4-8-17 & $1989-2008$ & Climate Limited-Area Modelling Community (Rockel et al. 2008) \\
REMO2009 & $1989-2008$ & Atmospheric Regional Model (Jacob 2001) \\
HadRM3P & $1990-2011$ & Met Office Hadley Centre Regional climate model version 3 (Jones et al. 2004) \\
HIRHAM5 & $1989-2010$ & High resolution Limited Area Model (HIRLAM) + General circulation models \\
& & for the atmosphere (ECHAM); (Christensen et al. 2006) \\
\hline
\end{tabular}

Table 3 AFR22 simulations used to compare ROM with RCMs

\begin{tabular}{lll}
\hline Model & Period & Description \\
\hline REMO2015 & 1980-2012 & $\begin{array}{l}\text { Atmospheric Regional Model (Jacob 2001) } \\
\text { Regional Climate Model system RegCM, originally developed } \\
\text { at the National Center for Atmospheric Research (Giorgi et al. } \\
\text { 2012) }\end{array}$ \\
1980-2010 & & Climate Limited-Area Modelling Community (Rockel et al. 2008) \\
\hline
\end{tabular}

Table 4 CMIP5 simulations used to compare ROM with GCMs

\begin{tabular}{|c|c|c|}
\hline Model & Spatial resolution & Description \\
\hline CNRM-CM5 & $1.4^{\mathrm{o}} \times 1.4^{\mathrm{o}}$ & $\begin{array}{l}\text { Centre National de Recherches Météorologiques Coupled Global Climate Model, version } 5 \text { (Voldoire } \\
\text { et al. 2013) }\end{array}$ \\
\hline EC-EARTH & $1.12^{\circ} \times 1.125^{\circ}$ & $\begin{array}{l}\text { The numerical wather prediction (NWP) system of the European Centre for Medium-Range Weather } \\
\text { Forecasts (ECMWF) forms the basis for EC-Earth (Hazeleger et al. 2010) }\end{array}$ \\
\hline IPSL-CM5A-MR & $1.25^{\circ} \times 2.5^{\circ}$ & $\begin{array}{l}\text { Institut Pierre Simon Laplace_Climate Modellling Centre Earth System Model version } 5 \text { (Dufresne et al. } \\
\text { 2013) }\end{array}$ \\
\hline HadGEM2-ES & $1.25^{\circ} \times 1.875^{\circ}$ & $\begin{array}{l}\text { Second version of Hadley Centre Global Environmental Model version } 2 \text { Earth System configuration } \\
\text { (Jones et al. 2011) }\end{array}$ \\
\hline
\end{tabular}

which provides daily averaged SST with a resolution of $5 \mathrm{~km}$ (Merchant et al. 2019).

- Latitudinal variability: Between the four major EBUSs, the CCUS stands out as the most spatially and seasonally variable one in terms of primary production (Sylla et al. 2019). Based on the seasonality, there are different arguments to divide the CCUS in sub-regions but without a broad consensus (Aristegui et al. 2009; Pardo et al. 2011; Cropper et al. 2014; Gómez-Letona et al. 2017; Fischer et al. 2019). Here we will focus on the seasonal and latitudinal variability of $\mathrm{T} 2 \mathrm{~m}$, wind and SST over the coastal band, allowing an integrated view of the coastal upwelling. The local wind was assessed using an upwelling index (UI) based on the offshore wind-driven Ekman transport (Q). The UI proposed by Bakun (1973) was calculated following the approach used by Gomez-Gesteira et al. (2006), Cropper et al. (2014) and Sousa et al. (2017a, b):
$Q_{x}=\frac{\tau_{y}}{f \rho}$

$Q_{y}=-\frac{\tau_{x}}{f \rho}$

$U I=-\sin \left(\theta-\frac{\pi}{2}\right) Q_{x}+\cos \left(\theta-\frac{\pi}{2}\right) Q_{y}$

where $\mathrm{Q}_{\mathrm{x}}, \mathrm{Q}_{\mathrm{y}}$ and $\tau_{x}, \tau_{y}$ are the zonal and meridional components of the horizontal Ekman transport and the wind stress vector, respectively; $\rho$ is the reference sea water density $\left(1025 \mathrm{~kg} \mathrm{~m}^{-3}\right)$; $f$ is the Coriolis parameter and $\theta$ is the angle between the coastline and the equator.

- Thermal vertical structure: The cross-shelf thermal vertical structure is relevant for the characterization of the coastal upwelling intensity. The vertical structure of the ocean temperature was assessed through SODA 
(Carton et al. 2018) and GLORYS12V1 (Drèvillon et al. 2018) gridded products and WOD18 (Boyer et al. 2019 ) in situ data. SODA3.4.1 is the latest version of SODA with $1 / 4^{\circ} \times 1 / 4^{\circ}$ resolution in 50 vertical levels. The GLORYS12V1 product is the Copernicus Marine Environment Monitoring Service (CMEMS) global ocean eddy-resolving reanalysis with observations assimilated from along track altimeter data, satellite sea surface temperature, sea ice concentration and in situ temperature and salinity vertical profiles. The WOD18 includes in situ measurements of temperature, salinity, dissolved oxygen and nutrients from 1773 to the present. For the evaluation we used a cross-shelf transect along $31^{\circ} \mathrm{N}$ (Cape Ghir), a region where the spatial resolution could play a role due to the bathymetry features and coastline.

- Mesoscale events: Coastal upwelling filaments are mesoscale structures with a great importance in the transport of organic carbon and nutrient-rich upwelled waters several hundred kilometers offshore and have typical lifetime of a few weeks (Menna et al. 2016), fueling the biological activity of the oligotrophic open waters (Lovecchio et al. 2018). We use two high resolution datasets able to detect the filaments: MODIS Aqua (Hall and Riggs 2007) and GLORYS12V1 (Drèvillon et al. 2018). The Moderate Resolution Imaging Spectroradiometer (MODIS) is a key instrument aboard Aqua satellite, which views the entire Earth's surface every 2 days, acquiring data in 36 spectral bands (Hall and Riggs 2007).

\subsection{Model intercomparison}

We use the Max Plank Institute for Meteorology_Earth System Model (MPI-ESM; Giorgetta et al. 2013) in order to assess the impact of the high resolution of ROM, particularly regarding mesoscale dynamics. MPI-ESM has the same ocean component (MPIOM) than ROM. Here we use the two versions of MPI-ESM contributing to CMIP5. The first, Low Resolution (-LR) uses for the ocean a bipolar grid with $1.5^{\circ}$ resolution. The Medium Resolution (-MR) has a tripolar grid with higher ocean horizontal resolution of $0.4^{\circ}$ (Giorgetta et al. 2013).

Additionally, we compare ROM output to the ensemble mean of several Regional Climate Models (RCMs) from the AFRICA-CORDEX, with boundary conditions forced by ERA-Interim. We should note that in AFRICA-CORDEX the available simulations are atmosphere-only and the horizontal resolution available were $0.22^{\circ}$ and $0.44^{\circ}$. Following Sousa et al. (2017b), we chose seven AFR44 (Table 2) and three AFR22 (Table 3) in the study.
Finally, also following Sousa et al. (2017a), ROM is compared with an ensemble of four Global Climate Models (GCMs) from the CMIP5 project (Table 4).

\section{Results}

\subsection{Larger scale}

In this section we assess the larger scale climate of the CCUS through the SST, the wind stress and the T2m from the Iberian Peninsula to Cape Blanc. Besides the coastal area, we also analyze an extensive offshore area that contains the CCUS (see the area of study in Fig. 2).

The mean SST field in the CCUS for the 1982-2012 period presents a year-round meridional gradient and a colder patch by the NW African and Iberian coasts because of the upwelled waters (Fig. 1a). For the evaluation of SST, we compare the output of ROM with OISST, MPI-ESMLR, MPI-ESM-MR and CMIP5 for the 1982-2012 period (Fig. 2). In DJF, ROM provides a good agreement with OISST, displaying biases smaller than $1.0^{\circ} \mathrm{C}$ over most of domain except for the northwest region, where the differences reach $2.5^{\circ} \mathrm{C}$ (Fig. 2a). MPI-ESM-LR and MPI-ESMMR present biases up to $2.0^{\circ} \mathrm{C}$ with larger differences at local regions such as Cape Bojador and Cape Blanc (Fig. 2b, c). CMIP5 ensemble mean shows an overall cold bias with a maximum in the Gulf of Cádiz (Fig. 2d).

In JJA, the cooling of coastal surface waters evidences the intensification of the upwelling system. This mechanism seems to be magnified by ROM, which despite of having small differences with OISST throughout the domain presents a cold bias of $2.0^{\circ} \mathrm{C}$ in the coastal strip between $24^{\circ} \mathrm{N}$ and $34^{\circ} \mathrm{N}$ (Fig. 2e), corresponding to the permanent upwelling zone with summer intensification (Arístegui et al. 2009). MPI-ESMs show a patchy bias distribution along the coast $\left(-2.0\right.$ to $\left.+2.0^{\circ} \mathrm{C}\right)$ presenting a cold bias $\left(3.0^{\circ} \mathrm{C}\right)$ in the northwest corner of the domain (Fig. 2f, g). CMIP5 biases present a similar patchy pattern but with lower values along the NW African coast (Fig. 2h), where the horizontal resolution seems to play an important role.

The interannual variability and the seasonal cycle of the spatially averaged SST were evaluated using OISST, ERA5 and ESA data sets (Fig. 3). ERA5 and ESA were added to the analysis to account for uncertainty on SST observationderived data. The time series of yearly spatially averaged ROM SST for the period 1980-2012 shows warm and cold biases ranging from +0.59 to $-0.28{ }^{\circ} \mathrm{C}$ compared to OISST (Fig. 3a), being mostly within the observation data sets spread range.

Figure $3 \mathrm{~b}$ shows the seasonal cycle of ROM SST compared to OISST, ERA5 and ESA. Minimum (maximum) temperatures are reached in February (September), being the 

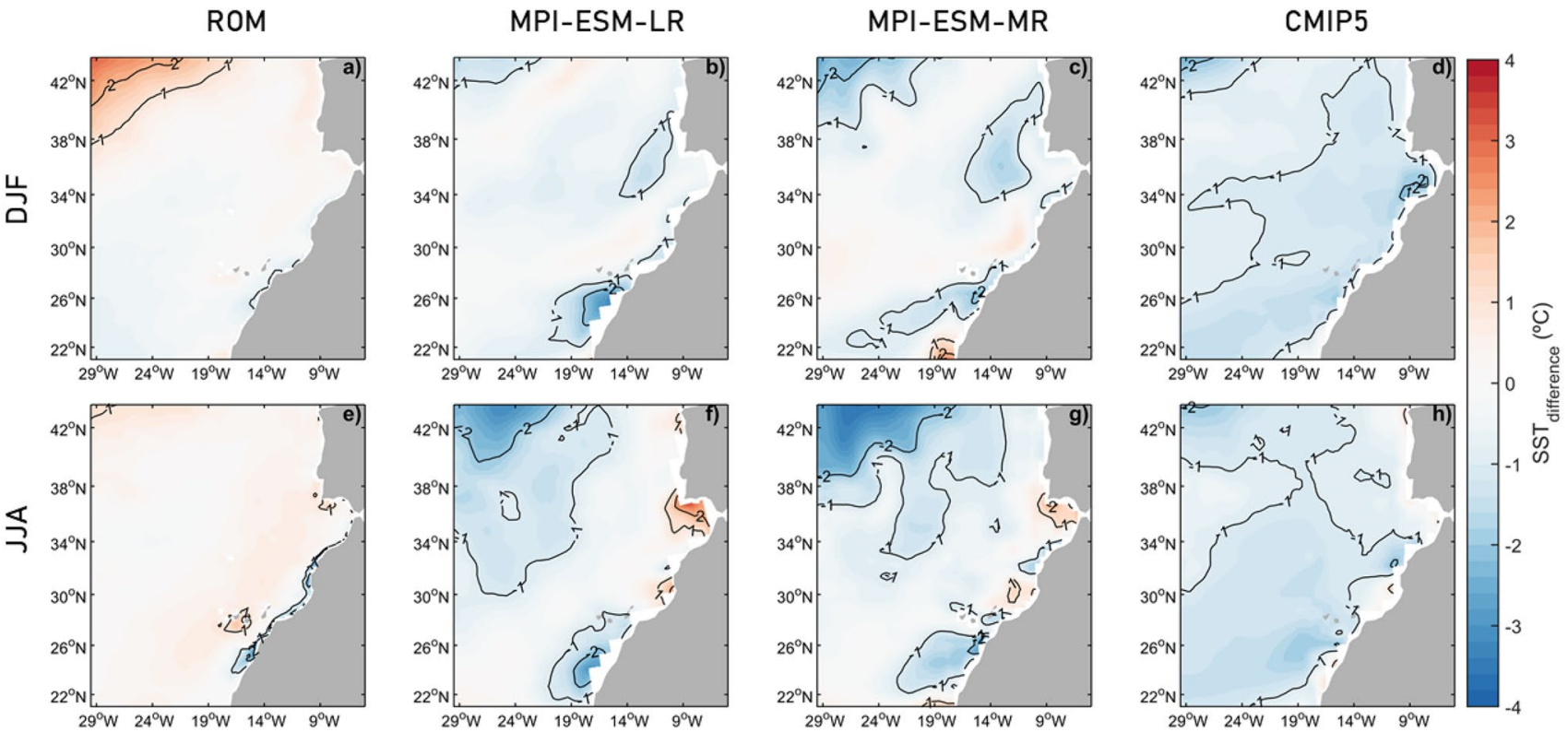

Fig. 2 SST biases $\left({ }^{\circ} \mathrm{C}\right)$ in DJF (upper row) and in JJA (lower row) between ROM (a, e), MPI-ESM-LR (b, f), MPI-ESM-MR (c, g) and CMIP5 $(\mathbf{d}, \mathbf{h})$ with OISST
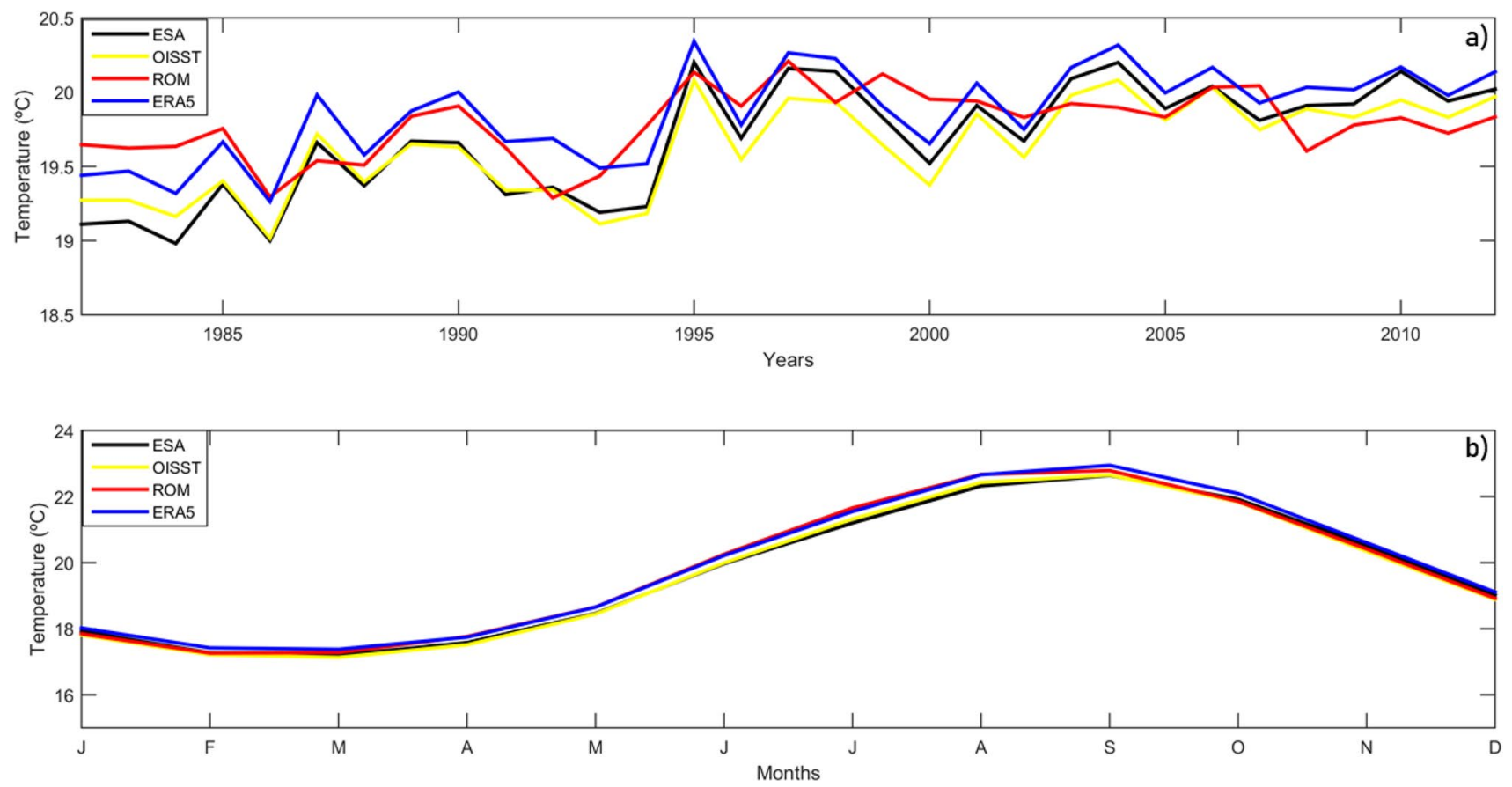

Fig. 3 a Times series of yearly mean (a) and seasonal cycle (b) (1982-2012) SST $\left({ }^{\circ} \mathrm{C}\right)$ averaged over the domain

amplitude of the seasonal cycle $5.4{ }^{\circ} \mathrm{C}$ for ESA and $5.5^{\circ} \mathrm{C}$ for ERA5, OISST and ROM.

Wind stress is the main driver of the CCUS (Fischer et al. 2019); erroneous intensities or directions of wind stress can have a strong impact on the seasonal upwelling system. To assess the ability of ROM reproducing the
CCUS we analyze the seasonal wind stress intensity and direction compared to ERA5, MPI-ESM-LR, MPI-ESMMR and CMIP5 during 1980-2012 period (Fig. 4). In DJF, when the anticyclonic circulation is weaker, the mean ERA5 wind stress intensity increases to north and south from $34^{\circ} \mathrm{N}$ where a zonal band with minimum 

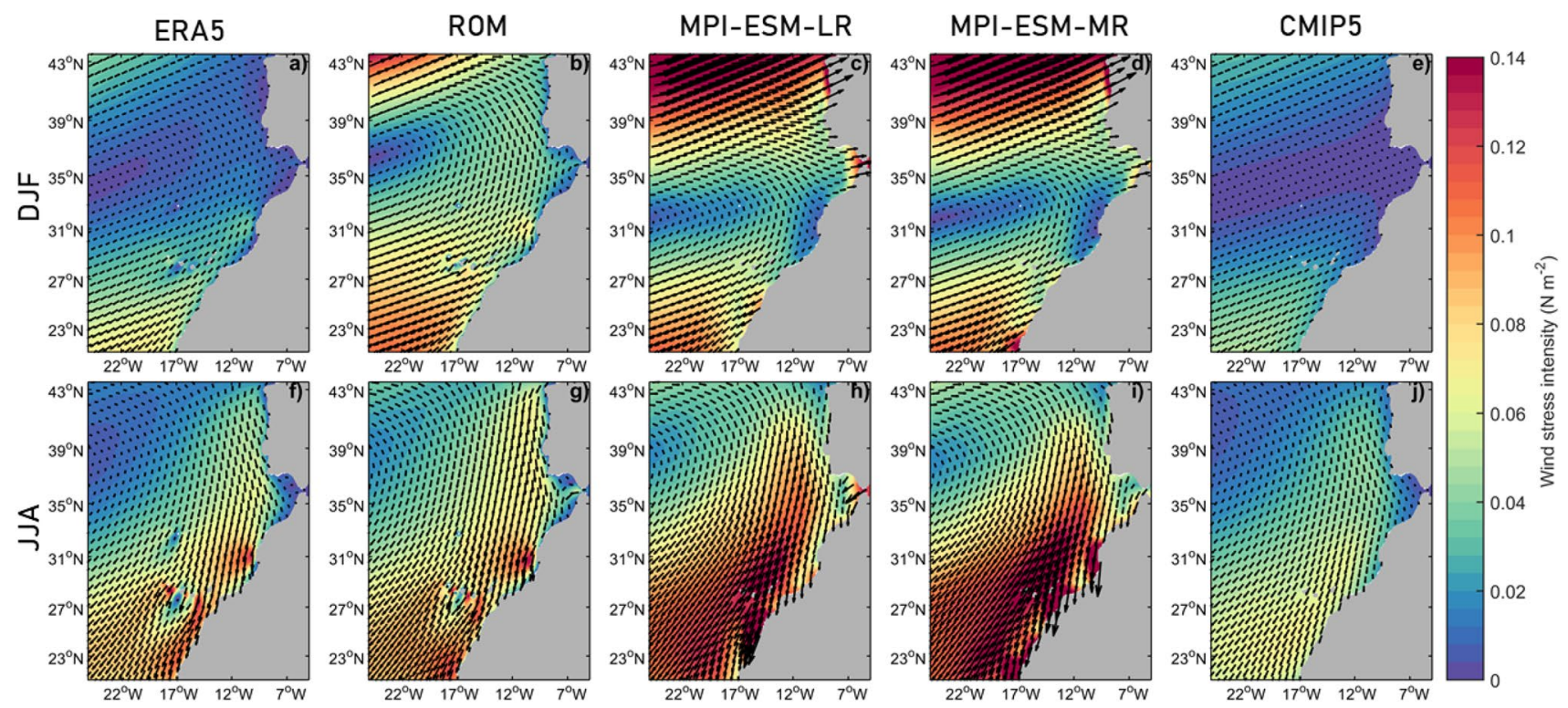

Fig. 4 a Wind stress intensity and direction for the winter (upper row) and summer (lower row) months. It is shown ERA5 (a, f), ROM (b, g), MPI-ESM-LR (c, h), MPI-ESM-MR (d, i) and CMIP5 (e, j)

values is located. Moreover, low wind stress values extend along the coasts of the Iberian Peninsula and NW Africa, increasing gradually to the south of the Canary islands (Fig. 4a). ROM overestimates the ERA5 wind stress due to an overestimation of the Azores high during the winter months (Fig. 4b). In both MPI-ESM runs (Fig. 4c, d) this overestimation is even larger. On the contrary, the CMIP5 ensemble mean underestimates the strength but shows a spatial pattern closer to the wind stress depicted by ERA5 (Fig. 4e). Despite the larger scale differences, ROM adequately represents the spatial pattern induced by coast in the wind stress because of its high horizontal resolution.

In JJA, the Azores high strengthens and migrates to the NW, where ERA5 shows the lower intensities of wind stress (Fig. 4f). In ERA5, the wind stress increases to the south showing the largest values in the coastal strip from Cape Ghir to the south, and downwind from Canary Islands. By the Iberian and NW African coastlines the wind direction is along the coast, i.e. upwelling favourable. As in winter, MPI-ESMs strongly overestimate the wind stress field strength (Fig. 4h, i), while CMIP5 underestimates it, but both properly reproduce the wind stress field directions (Fig. 4j). Improving on the GCMs performance, ROM reproduces the JJA wind stress field remarkably well, including smaller scale features such as the local maximum off Cape Ghir, the Madeira and Canary Islands shadowing effect, the wind intensification in the passage between Canary Islands and Africa or the coastal weakening effect (Fig. 4g).

\subsection{Latitudinal variability over the coastal band}

The CCUS is a dynamically complex system with a large spatial and seasonal variability. Here, we will assess SST, wind and $\mathrm{T} 2 \mathrm{~m}$ variability focusing on the coastal band as the upwelling front is located within a few degrees offshore from the shelf break (Pelegrí and Bennazzouz 2015), supplementing the analysis of the previous section.

The coastal cold SST is a key indicator to determinate the intensity of the upwelling system. The seasonal cycle of ROM was compared with the seasonal cycle of OISST over the coastal band (the mask is shown in Fig. 1a with red lines) and with the GCMs (MPI-ESM-LR, MPI-ESM-MR and CMIP5 ensemble). ROM performs better than GCMs with biases smaller than $0.5^{\circ} \mathrm{C}$ in winter. It is also evident the effect of the coarse resolution in GCMs, especially in MPI-ESM-LR and CMIP5 (Fig. 5a-d).

In summer boreal months, when the Canary upwelling intensifies, ROM shows very small warm biases north of the Strait of Gibraltar and cold biases in the region of the NW African coast (Fig. 5e). Remarkably at $25^{\circ} \mathrm{N}$ ROM cold bias extends uniformly offshore. MPI-ESM-LR shows the largest warm biases (up to $3.0^{\circ} \mathrm{C}$ ) in Cape Ghir and the Gulf of Cádiz. MPI-ESM-MR and CMIP5 present cold biases in the Gulf of Cádiz and Cape Bojador $\left(2.0^{\circ} \mathrm{C}\right)$ and warm biases in Cape Ghir and Cape Blanc (Fig. 5g, h).

From these results it could be concluded that ROM magnifies in summer the upwelling in the zone of weak permanent upwelling located between $25^{\circ} \mathrm{N}$ and $33^{\circ} \mathrm{N}$ (Cropper et al. 2014; Gómez-Letona et al. 2017). To clarify the role 

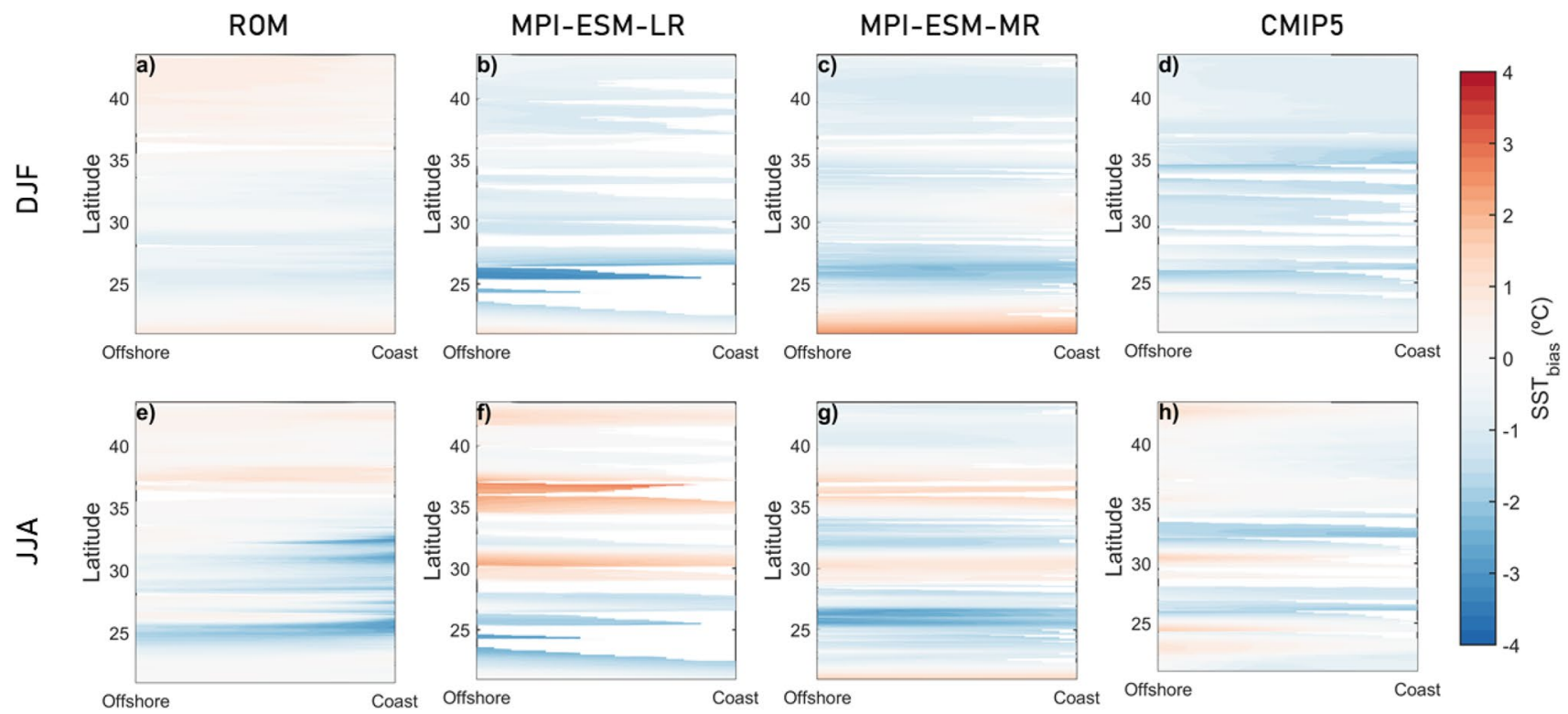

Fig. 5 SST $\left({ }^{\circ} \mathrm{C}\right.$ ) biases in the closest grid-points to the coast (red line Fig. 1a; $100 \mathrm{~km}$ from Coast to Offshore), between ROM (a, e), MPI-ESMLR (b, f), MPI-ESM-MR (c, g) and CMIP5 (d, h) with OISST, in DJF (upper row) and JJA (lower row)

DJF

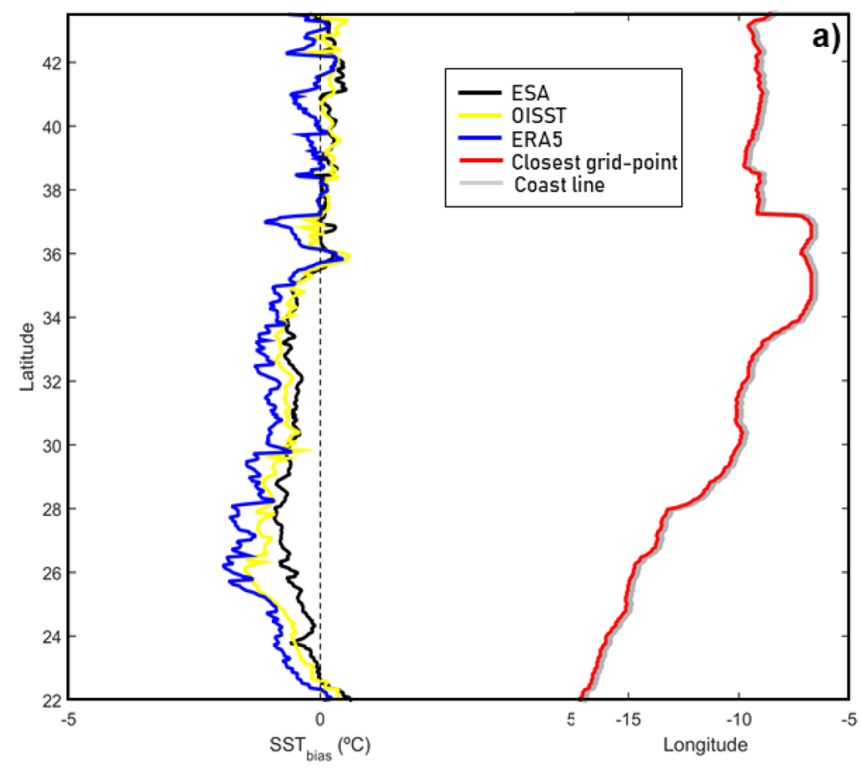

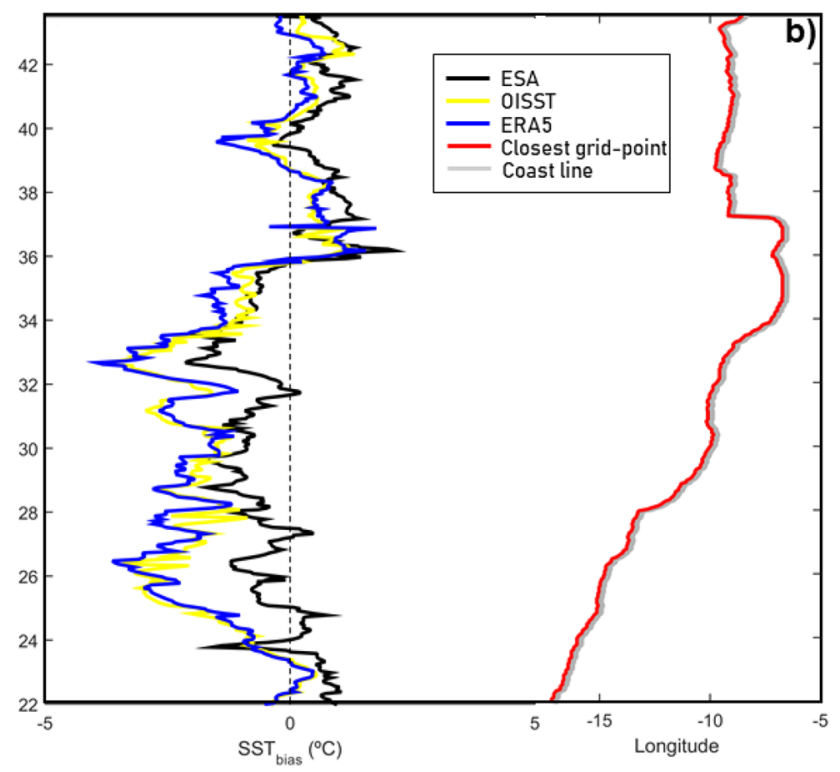

Fig. 6 ROM SST $\left({ }^{\circ} \mathrm{C}\right)$ biases in the closest grid-point to coast with OISST, ESA and ERA5, in DJF (a) and JJA (b)

of the high resolution in this issue we compared the ROM biases with respect to OISST, ERA5 and ESA in the grid points that are closer to the coast (Fig. 6). In DJF ROM biases are similar for the three datasets, with cold biases smaller than $1.0^{\circ} \mathrm{C}$ along the African coast. From Cape Ghir to Cape Blanc, the biases with ESA are notably smaller (Fig. 6a). In JJA, the differences in the biases increase, being close to $0.5^{\circ} \mathrm{C}$ in Cape Ghir and Cape Bojador for ESA and reaching the $4.0^{\circ} \mathrm{C}$ for ERA5 at those locations (Fig. 6b). In general, ROM differences with ESA are smaller than with OISST and ERA5 along the African coast. The reason for these discrepancies can be related to the OISST and ERA5 resolution, which does not allow for a clear representation of the SST coastal pattern of the upwelling.

The coastal wind stress was assessed through UI (Fig. 7) in order to quantify the upwelling intensity from Ekman 

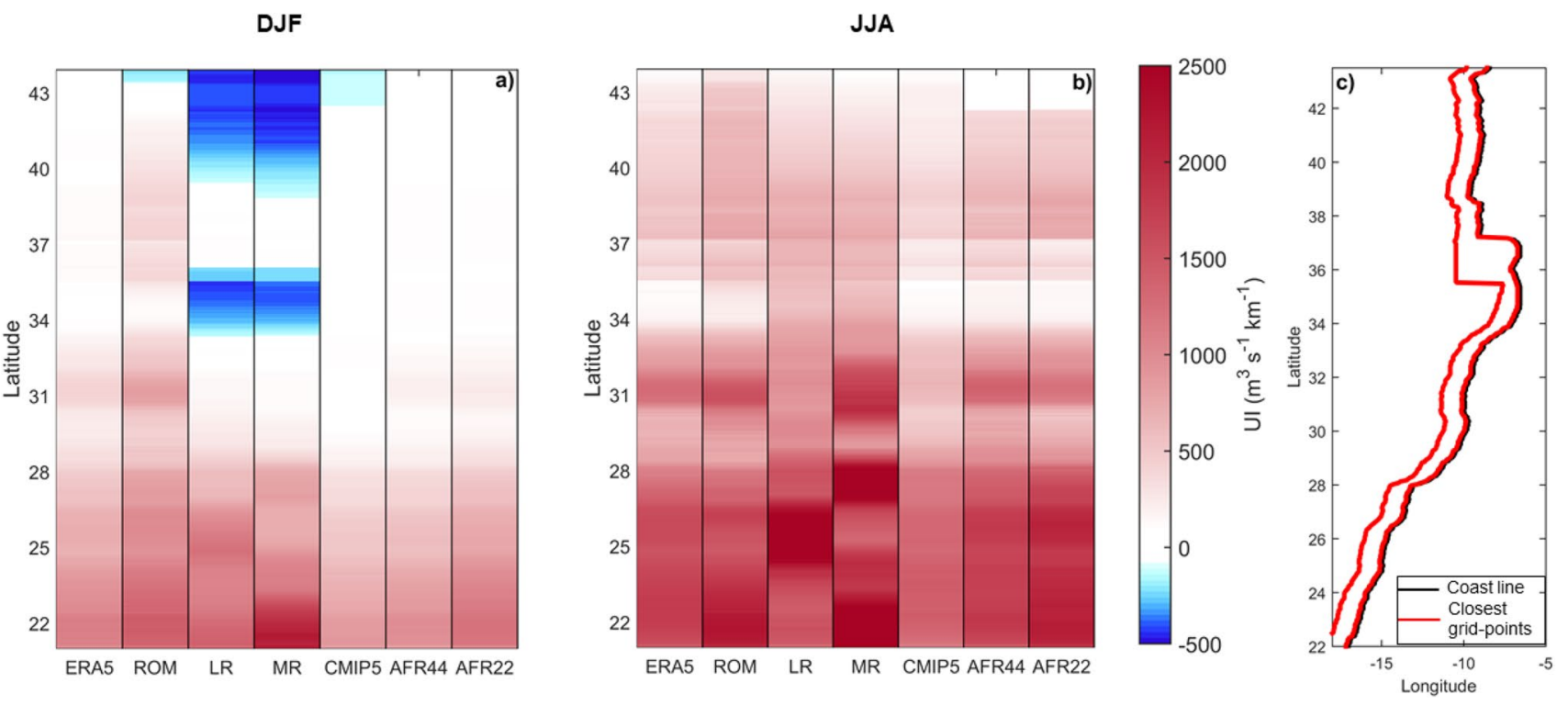

Fig. 7 UI $\left(\mathrm{m}^{3} \mathrm{~s}^{-1} \mathrm{~km}^{-1}\right)$ averaged over the closest grid-points to the coast (c), for DJF (a) and JJA (b). ROM is assessed with ERA5 and compared with MPI-ESM-LR, MPI-ESM-MR, CMIP5, AFR44 and AFR22

Table 5 Latitudinal coefficient of determination for UI averaged over the closest gridpoints to coast in DJF and JJA, comparing ERA5 with ROM, MPI-ESM-LR, MPI-ESM-MR, CMIP5, AFR44 and AFR22

\begin{tabular}{lcc}
\hline & DJF & JJA \\
\hline ROM & 0.96 & 0.94 \\
MPI-ESM-LR & 0.90 & 0.71 \\
MPI-ESM-MR & 0.92 & 0.72 \\
CMIP5 & 0.96 & 0.92 \\
AFR44 & 0.98 & 0.98 \\
AFR22 & 0.96 & 0.96 \\
\hline
\end{tabular}

transport. Positive (negative) UI corresponds to upwelling (downwelling) conditions. In DJF (Fig. 7a), ERA5 presents nearly neutral conditions along the coasts of the Iberian Peninsula. From the Gulf of Cádiz to Cape Ghir ERA5based UI is positive increasing towards the south, where from Cape Bojador to Cape Blanc the upwelling becomes intense. This latitudinal variability is well represented by ROM and AFRICA-CORDEX (AFR44 and AFR22), highlighting higher values in ROM for Cape Ghir and in southern regions and weaker in AFRICA-CORDEX for the region between the Gulf of Cádiz to Cape Blanc. CMIP5 also represents reasonably well the latitudinal variability, although it is smoother and with a general tendency to underestimate the upwelling index.

In JJA, ERA5-based UI shows upwelling conditions along the Iberian coast and a clear intensification of the upwelling by the NW African coast, appearing a local maximum between Cape Beddouza and Cape Ghir $\left(30.5^{\circ} \mathrm{N}-32.5^{\circ} \mathrm{N}\right)$. ROM and AFRICA-CORDEX present the same latitudinal pattern as ERA5, while CMIP5 reproduces the latitudinal variability, but with lower values of the UI and MPI-ESMs show different local maxima. In general, AFRICA-CORDEX shows a slightly better performance than ROM and CMIP5, with MPI-ESMs having the worst coefficients of determination (Table 5).

The T2m land-sea difference lies in the ground of Bakun's (1990) hypothesis of change in upwelling systems under global warming. The land-sea gradient simulated by ROM is validated against ERA5 and compared with MPIESM-LR, MPI-ESM-MR, CMIP5 and AFRICA-CORDEX simulations. For each latitude, we calculate the difference between the $2 \mathrm{~m}$ air temperature zonally averaged over $100 \mathrm{~km}$ inshore (bounded by the red line, land) and zonally averaged over $100 \mathrm{~km}$ offshore (bounded by the blue line, ocean) as shown in the Fig. 8c.

ERA5 T2m land-sea differences present mostly negative values in DJF, changing sign in the southern part from $21^{\circ} \mathrm{N}$ to $23^{\circ} \mathrm{N}$ (Cape Blanc). AFICA-CORDEX reproduces accurately the latitudinal variability, while ROM and CMIP5 fail in simulating the sign change in the southernmost region. The MPI-ESMs do not reproduce properly the latitudinal variability and show too low values of the T2m land-sea difference (around $0.5^{\circ} \mathrm{C}$ ).

In JJA the insolation increases and the land becomes warmer than the sea, so T2m land-sea differences are mostly positive (Fig. 8b). ERA5 presents a high latitudinal variability, with two regions showing the largest positive differences (Cape Ghir and from Cape Bojador to Cape Blanc). ROM and AFRICA-CORDEX again reproduce well the T2m landsea differences. CMIP5 does not reproduce properly the T2m land-sea differences latitudinal pattern, showing a spurious maximum in the Gulf of Cádiz, and the MPI-ESMs showed 

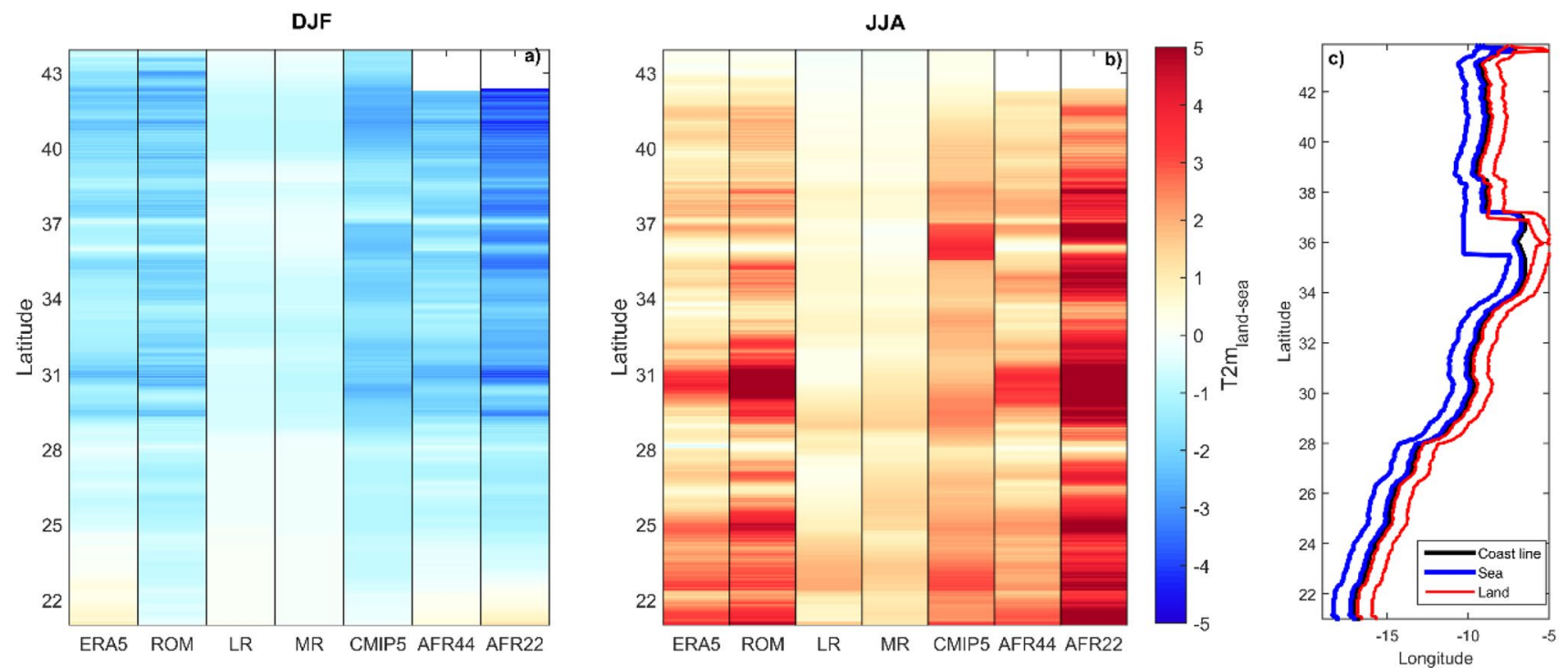

Fig. 8 Along-shore land (c; blue)—sea (c; red) temperature difference $\left({ }^{\circ} \mathrm{C}\right)$ for DJF $(\mathbf{a})$ and JJA (b). ROM is assessed with ERA5 and compared with MPI-ESM-LR, MPI-ESM-MR, CMIP5, AFR44 and AFR22

very low values compared to those of ERA5. AFRICACORDEX and ROM show a better performance, especially in summer when CMIP5 and MPI-ESMs present a rather low coefficient of determination (Table 6).

\subsection{Thermal vertical structure}

The cross-shelf thermal vertical structure is commonly used to characterize coastal upwelling. The thermal vertical structure of the upper $200 \mathrm{~m}$ simulated by ROM was compared to SODA and GLORYS reanalysis and to in-situ data from WOD18. We choose a cross-shelf transect at Cape Ghir $\left(31.5^{\circ} \mathrm{N}\right)$. All observations used from WOD18 were taken between 1980 and 2012, and the isotherms were plotted as a qualitative reference (Fig. 9a, b).

At Cape Ghir WOD18 presents a clear thermal stratification, more evident in summer, with isotherms sloping up to the coast and a temperature range between $14{ }^{\circ} \mathrm{C}$ and $22{ }^{\circ} \mathrm{C}$. In summer the upwelling front outcrops in the surface near $10.3^{\circ} \mathrm{W}$ (see $17^{\circ} \mathrm{C}$ isotherm), while it is relaxed in winter with the $17^{\circ} \mathrm{C}$ isotherm outcropping more to the east by the coast (Fig. 9a, b). The cross-shelf structure and seasonality is

Table 6 Latitudinal coefficient of determination for $\mathrm{T} 2 \mathrm{~m}$ land-sea differences averaged over the closest grid-points to coast in DJF and JJA, comparing ERA5 with ROM, MPI-ESM-LR, MPI-ESM-MR, CMIP5, AFR44 and AFR22

\begin{tabular}{lcc}
\hline & DJF & JJA \\
\hline ROM & 0.85 & 0.77 \\
MPI-ESM-LR & 0.71 & 0.30 \\
MPI-ESM-MR & 0.64 & 0.34 \\
CMIP5 & 0.71 & 0.30 \\
AFR44 & 0.94 & 0.76 \\
AFR22 & 0.92 & 0.68 \\
\hline
\end{tabular}

properly represented by GLORYS and SODA reanalysis, but ROM is more accurate in the representation of the vertical gradients and the isotherm sloping by the coast (Fig. 9c-h).

\subsection{Upwelling filaments}

The MPIOM high horizontal resolution in the central region of the CCUS allows marginally the representation of the mesoscale variability because the climatological first baroclinic Rossby radius of deformation is around $30 \mathrm{~km}$ in this area (Chelton et al. 1998). Upwelling filaments are elongated mesoscale structures of upwelled water extending offshore in the upper surface layer (Brink 1983). Alvarez-Salgado et al. (2007) and Lovecchio et al. (2018) highlighted the relevant contribution of upwelling filaments to offshore organic carbon in the CCUS. The most prominent filaments in the CCUS are located at Cape Ghir, Cape Juby, Cape Bojador and Cape Blanc. Cape Ghir filament, one of the largest and existing nearly all year round (Hagen et al. 1996), exports large amounts of organic material into the open ocean (García-Muñoz et al. 2005; Pelegrí et al. 2005, 2006). To assess ROM skills in reproducing these relevant mesoscale features we use two filament events in August 2006 and August 2009, the latter studied in detail by Sangrá (2015) and Sangrá et al. (2015). We compare the observed MODIS Aqua SST with ROM and GLORYS output averaged for 21st to 28th August 2006 and 13th to 20th August 2009 (Fig. 10).

As described by Sangrá et al. (2015), ROM reproduces the filament cold core, with SST below $19{ }^{\circ} \mathrm{C}$ and a broader cool embracing region with temperatures between $19^{\circ} \mathrm{C}$ and $21^{\circ} \mathrm{C}$. ROM reproduces properly both filament events, quite accurately the offshore extension of the embracing region 

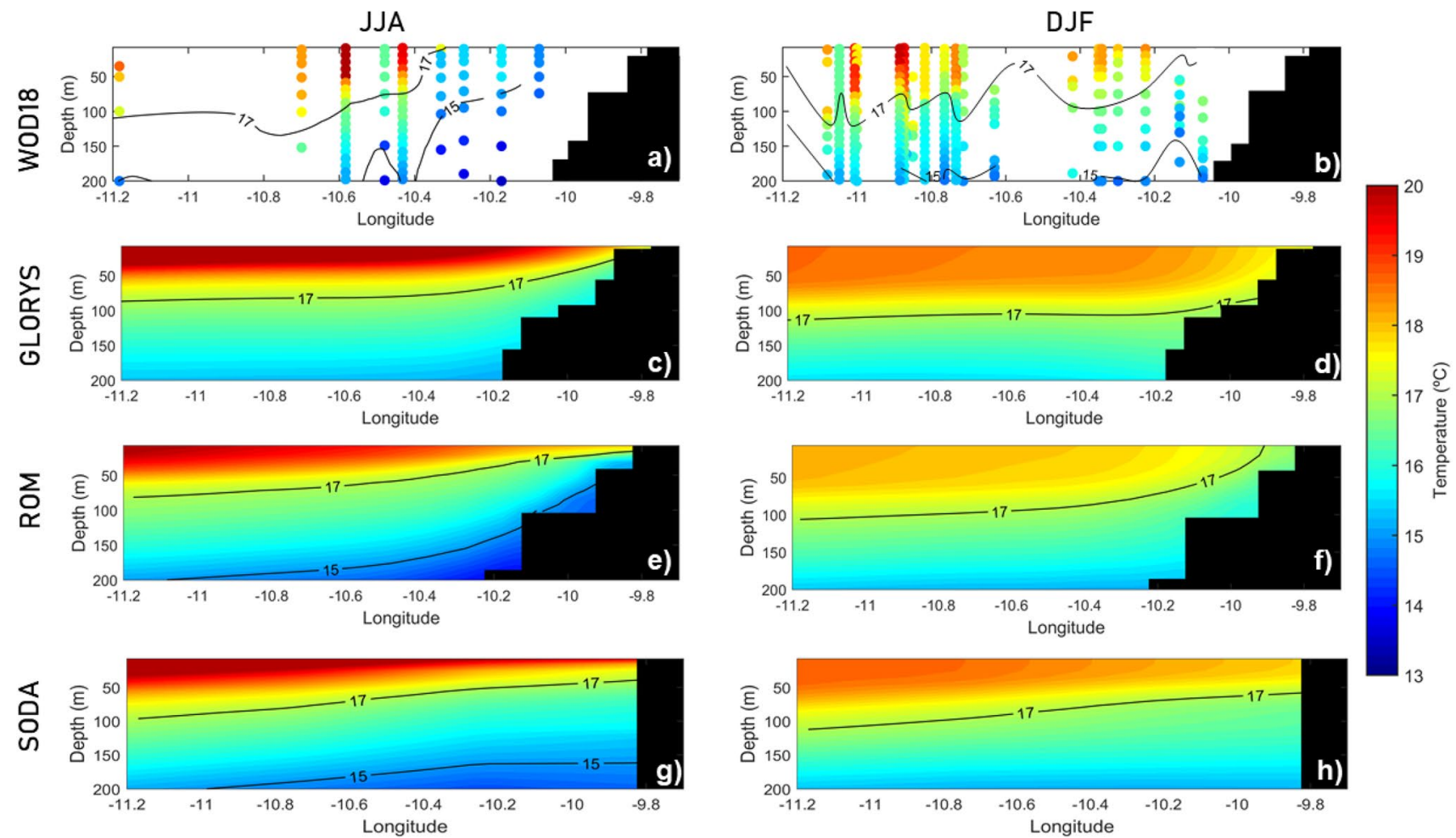

Fig. 9 Temperature $\left({ }^{\circ} \mathrm{C}\right)$ transect for JJA (left) and DJF (right) in Cape Ghir (1980-2012) for WOD18 (a, b), GLORYS (c, d), ROM (e, f) and SODA $(\mathbf{g}, \mathbf{h})$
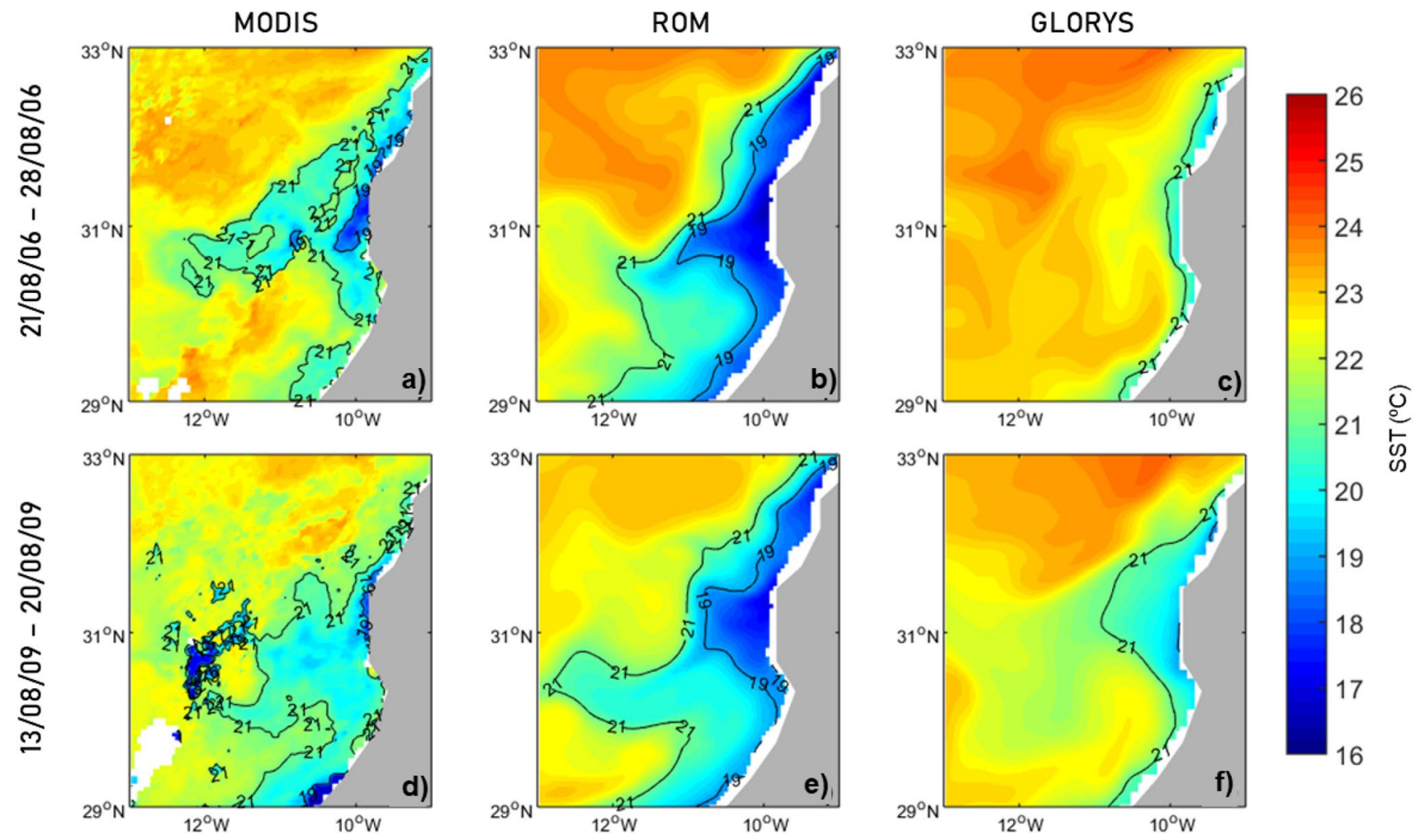

Fig. 10 Averaged SST $\left({ }^{\circ} \mathrm{C}\right.$ ) in 21-28 August of 2006 (upper row) and 13-20 August of 2009 (lower row) for MODIS Aqua (a, d), ROM (b, e) and GLORYS (c, f) 
and a overextended cold core, while GLORYS filament is excessively limited to the coast.

\section{Discussion}

When Bakun (1990) formulated his hypothesis highlighting that under global warming the increase in ocean-land temperature contrast may oppose the general tendency for ocean-basin scale circulation to slow down, the enormous uncertainty about the evolution of coastal ocean upwellings under global climate change conditions was evidenced. Additionally, the importance of the mesoscale in the decadal changes of the CCUS is widely acknowledged (e. g. Relvas et al. 2009), as it is the role of the mesoscale in transporting nutrients and phytoplankton (e.g. Gruber et al. 2011). Since then many attempts have been done to get rid of such uncertainty and to deepen the knowledge about the behaviour of such fundamental marine ecosystems under global warming conditions, and different observational and model products have been used to resolve the different scales relevant for these questions. The study of the upwelling systems in the CMIP5 simulations (e. g. Oyarzun and Brierley et al. 2018) allowed identifying the climate change drivers and the main limitations of the GCMs to reproduce the mesoscale processes in the EBUSs (Garcia-Reyes et al. 2015; Bindoff et al. 2019). These local and mesoscale features may have greater impact on EBUSs than large-scale wind patterns (Renault et al. 2016; Xiu et al. 2018). The difficulties found in the representation of the CCUS by global models can be significantly resolved with the help of high resolution AORCMs (e. g. Xiu et al. 2018). In this work, the use of ROM in the CCUS region allows us to represent the finescale atmosphere-ocean feedback, reproducing the spatial and temporal structure needed in the regional climates $(\mathrm{Li}$ et al. 2012; Sein et al. 2015). Moreover, ROM configuration allows a high resolution in the region of interest maintaining a global ocean domain (Soares et al. 2018; Parras-Berrocal et al. 2020).

The provided climate assessment shows that ROM reproduces the basin scale climate and the seasonal signal affecting the CCUS (Sect. 3.1) better than the GCMs (MPIESMs and CMIP5) and is in good agreement with OISST and ERA5. ROM presents also good skills in reproducing the interannual variability of the basin scale SST when compared to ERA5, OISST and ESA data sets (Fig. 3). However, in winter ROM has a warm bias in the northwest corner of the domain (Fig. 2a). We have also identified an overestimation of the Azores high in winter, originating a wrong wind stress field representation along the West Iberian coast (Fig. 4b). Parras-Berrocal et al. (2020) attributed those differences to the role played by the deficiencies of ROM to simulate the ocean circulation in the North Atlantic, with a cold bias centred east of Flemish Cap. Other studies stand out the difficulties of the ocean models to simulate the Gulf Stream in winter (Eden and Greatbatch 2003; Bryan et al. 2007) and Cabos et al. (2020) detected those deficiencies not only in the ocean models, but also in the Climate Forecasting System Reanalysis. However, according to our results the impact of those winter basin-scale inaccuracies on the CCUS seems to be quite limited, as they impact mostly in the West Iberian coast during the no upwelling season.

ROM also presents a cold bias compared to OISST along the NW African coast in summer, when the upwelling intensifies (Figs. 2 and 5). Mason et al. (2011) and Santana-Falcón et al. (2020) found a similar cold bias in their ocean regional models over the CCUS, attributing it to the warm bias in SST forcing data set identified by Dufois et al. (2012) in a number of modelling studies in the world EBUS. According to Dufois et al. (2012) the cause of the SST warm coastal bias in monthly Pathfinder data during summer was a flagging method based on an OISST reference test, which is explained by strong coastal SST gradients in these regions, which cannot be satisfactorily represented by the large scale OISST product. This drawback of OISST can partly explain the strong cold bias in ROM with respect to this observational product. Indeed, when we compared ROM SST with a higher resolution dataset (ESA) the cold bias was notably reduced (Fig. 6), demonstrating the importance of the high resolution in mesoscale regions as the CCUS.

This high ocean resolution is key for the representation of the CCUS mesoscale, which is determined by the accuracy in the representation of the coastal wind stress field and the land-ocean temperature contrast and characterized by the cross shelf thermal structure and the generation of events such as upwelling filaments.

ROM properly distinguishes the three main CCUS subregions (e.g. Aristegui et al. 2009, Cropper et al. 2014; Gómez-Letona et al. 2017) from the UI (Fig. 9): from $21^{\circ}$ $\mathrm{N}$ to $26^{\circ} \mathrm{N}$ (permanent upwelling zone), from $26^{\circ} \mathrm{N}$ to $33^{\circ}$ $\mathrm{N}$ (weak permanent upwelling zone) and from $33^{\circ} \mathrm{N}$ to $43^{\circ}$ $\mathrm{N}$ (seasonal upwelling zone), although in part of the West Iberian coast ROM produces a nearly year-round upwelling (Fig. 7) as a consequence of the misrepresentation of the wind field in that area as previously discussed. Despite this fact, ROM performs better than the MPI-ESMs and the CMIP5 ensemble, and slightly worse than the AFRICACORDEX ensemble in terms of the UI (which is calculated from the wind stress). It must be taken into account that, the lowest resolution of AFRICA-CORDEX configuration (AFR44) reproduces better the latitudinal variability than higher resolution (AFR22). This fact may be related to the smaller ensemble in AFR22 (only 3 members vs 7 members in AFR44) and the different regional models in both ensembles. Moreover, although AFR44 models have lower horizontal resolution than ROM atmosphere $\left(0.44^{\circ}\right.$ 
vs $0.22^{\circ}$ ) their west and north boundaries, forced by ERAInterim, are pretty close to the CCUS and that the SST is also prescribed from ERA-Interim. The UI values along the Iberian Peninsula simulated by ROM are similar to other studies, with a localised downwelling by the Galician coasts $\left(-200 \mathrm{~m}^{3} \mathrm{~s}^{-1} \mathrm{~km}^{-1}\right)$ in winter and weak upwelling (500 $\mathrm{m}^{3} \mathrm{~s}^{-1} \mathrm{~km}^{-1}$ ) in the summer months (Pardo et al. 2011; Sousa et al. 2017a). The upwelling in the African coast also is in the range obtained by different studies (Pardo et al. 2011; Sousa et al. 2017b), with year-round permanent upwelling (from 600 to $1000 \mathrm{~m}^{3} \mathrm{~s}^{-1} \mathrm{~km}^{-1}$ ) in winter, increasing to $1500 \mathrm{~m}^{3} \mathrm{~s}^{-1} \mathrm{~km}^{-1}$ in the African coastline.

The $\mathrm{T} 2 \mathrm{~m}$ land-sea difference and its latitudinal variability is relevant for CCUS representation as Bakun hypothesis is based on the global warming induced changes in the T2m land-sea differences. Several authors (Sydeman et al. 2014; Wang et al. 2015) supported Bakun's proposition, but remains unclear the relationship between coastal wind intensification and global warming (García-Reyes et al. 2015). Our results have shown a good performance of ROM representing the T2m land-sea contrast variability in CCUS as compared to ERA5. The latitudinal variability of the land sea temperature contrast is strongly reduced in the GCMs, indicating that global models have difficulties to represent the land-sea thermal differences in coastal regions (Ning et al. 2014; Roxy et al. 2015; Ward et al. 2020). ROM does not reproduce the sign change of $\mathrm{T} 2 \mathrm{~m}$ land-sea difference in Cape Blanc, while it is properly captured by AFRICACORDEX. In JJA, ROM overestimates the T2m land-sea differences in Cape Ghir as a consequence of a strong warming in the Atlas mountains.

Therefore, the ROM improvement over the GCMs and good performance as compared to AFRICA-CORDEX shows the impact of the higher resolution and coupling for CCUS climate modelling. Coming to details, we have identified the Cape Ghir as an intense upwelling location both in DJF as JJA, and as a place where upwelling filaments are a nearly permanent mesoscale feature. ROM properly reproduces the summer increase in ocean thermal stratification in the upper $100 \mathrm{~m}$ at Cape Ghir and the increase in the slope of the isotherms in the immediate proximity to the coast (Fig. 9), comparing well with WOD18 hydrographic data and with GLORYS reanalysis. The improvement over SODA is remarkable, especially over the shelf where the high resolution plays a key role.

The mesoscale events play an important factor over the CCUS, where only organic carbon export by filaments in the subtropical northeast Atlantic contributes to the $63 \%$ of the annual primary production associated with the coastal upwelling (Santana-Falcón et al. 2016, 2020). ROM reproduces the two selected events in Cape Ghir, exporting the water masses from coast to $150 \mathrm{~km}$ offshore (Fig. 10). Quite often limited area models are used for reproducing these events with the difficulties of dealing with the open boundary conditions. This is even more important when considering the biogeochemical relevance of the upwelling filament dynamics. Troupin et al. (2012) and Santana-Falcón et al. (2020) approached the study of upwelling filaments using nested domains and a one-way offline coupling. However, when the focus is on the basin-scale, approaches accounting for the influence of the mesoscale on the larger scale are needed. Lovecchio et al. $(2017,2018)$ used such an approach by means of a telescopic curvilinear grid with strong refinement in the NW African coast, being able to highlight the key role of mesoscale processes in the offshore transport of organic carbon and concluding that a great part of this flux out of the upwelling regions is not accounted for in coarse global models. Here, we present a model approach capable of reproducing the large-scale climate signal accounting for the relevant upwelling mesoscale dynamics, which is of uttermost importance to assess the future evolution of CCUS and its socio-economic consequences under climate change scenarios.

\section{Conclusions}

In the present work, we assess the ability of the atmosphere-ocean regionally coupled model ROM to represent the large-scale climate and mesoscale processes involved in the CCUS dynamics, and compare it to two MPI-ESMs configurations and ensembles of CMIP5 GCMs and AFRICA-CORDEX RCMs. Our findings can be summarized as follows:

- ROM shows a better performance than the MPI-ESMs and CMIP5 models in representing the larger-scale wind stress and SST fields, although a relatively overestimation of the Azores high in winter affects slightly the CCUS over the West Iberian coast. Besides, ROM reproduces adequately the seasonal and interannual variability of the ERA5, ESA and OISST.

- High resolution is key to reproduce the latitudinal variability of the CCUS, as ROM represents the observed coastal SST with higher accuracy than the GCMs. Moreover, ROM successfully reproduces the coastal UI as well as the T2m land-sea differences, highlighting the impact of the higher resolution against the GCMs with a performance comparable to AFRICA-CORDEX.

- The mesoscale processes in the CCUS are well simulated by ROM, which is able to transfer the coastal upwelling waters to the open ocean in a realistic way. Thus, it successfully represents two coastal upwelling filaments off Cape Ghir, which are not accounted for in most global models. 
In conclusion, ROM is a powerful atmosphere-ocean model system able to reproduce with accuracy the CCUS, performing better than the GCMs. The improvement is related to a much higher horizontal resolution, which allows a better simulation of the dominant mesoscale coastal dynamics. The results here give ground to the future use of ROM to gain a deeper insight into the CCUS by the end of twenty-first century.

Acknowledgements The authors acknowledge the Copernicus marine services (http://marine.copernicus.eu), because this study has been conducted using CMEMS modeled products (GLORYS12v1) and observational data sources (ESA). The authors also thank the coordinating body of AFRICA-CORDEX (http://www.csag.uct.ac.za/cordex-africa) and the responsible panel for CMIP5. This work has been developed within the framework of the European Cooperation Project Interreg VA España-Portugal "OCASO" (Southwest Coastal Environmental Observatory, 0223_OCASO_5_E). Dmitry Sein was supported in the framework of the state assignment of the Ministry of Science and Higher Education of Russia (No. 0128-2021-0014). This work used resources of the Deutsches Klimarechenzentrum (DKRZ) granted by its Scientific Steering Committee (WLA) under project ID ba0987.

Funding Open Access funding enabled and organized by Projekt DEAL. Ruben Vazquez was supported through a doctoral grant at the University of Ferrara and University of Cádiz. Dmitry Sein was supported in the framework of the state assignment of the Ministry of Science and Higher Education of Russia (No. 0128-2021-0014). This work used resources of the Deutsches Klimarechenzentrum (DKRZ) granted by its Scientific Steering Committee (WLA) under project ID ba0987.

Availability of data and materials The ROM data are available at https://swiftbrowser.dkrz.de/public/dkrz_64ea1a99f1de45dab8d1a3175 f15ee46/ROM_CCUS_data/ (Sein et al. 2015). The ERA5 data can be found at https://cds.climate.copernicus.eu/\#!/search?text=ERA5\& type $=$ dataset. The OISST datasets were downloaded from the NOAA website (https://www.ncdc.noaa.gov/oisst, Reynolds et al. 2007). The MPI-ESMs (Giorgetta et al. 2013) and CMIP5 models were downloaded from https://cera-www.dkrz.de/WDCC/ui/cerasearch/. The WOD18 data were downloaded from https://www.ncei.noaa.gov/ products/world-ocean-database (Boyer et al. 2019). SODA (Carton et al. 2018) data are available at http://dsrs.atmos.umd.edu/DATA/ soda3.4.1/REGRIDED/ocean/. ESA (Merchant et al. 2019) and GLORYS (Drèvillon et al. 2018) data were downloaded from Copernicus Marine and Enviroment Monitoring Service (CMEMS) (https://resou rces.marine.copernicus.eu/?option $=$ com_csw\&task=results\&pk_vid $=$ d187b75caef568191616665922eff32d). MODIS (Hall and Riggs 2007) data are available at https://oceancolor.gsfc.nasa.gov/13/. RCMs are available from the AFRICA-CORDEX initiative (https://esgf-data.dkrz. de/projects/esgf-dkrz/).

Code availability Not applicable for that section.

\section{Declarations}

Conflict of interest The authors have no conflicts of interest to declare that are relevant to the content of this article.

Open Access This article is licensed under a Creative Commons Attribution 4.0 International License, which permits use, sharing, adaptation, distribution and reproduction in any medium or format, as long as you give appropriate credit to the original author(s) and the source, provide a link to the Creative Commons licence, and indicate if changes were made. The images or other third party material in this article are included in the article's Creative Commons licence, unless indicated otherwise in a credit line to the material. If material is not included in the article's Creative Commons licence and your intended use is not permitted by statutory regulation or exceeds the permitted use, you will need to obtain permission directly from the copyright holder. To view a copy of this licence, visit http://creativecommons.org/licenses/by/4.0/.

\section{References}

Álvarez-Salgado XA, Arístegui J, Barton ED, Hansell DA (2007) Contribution of upwelling filaments to offshore carbon export in the subtropical Northeast Atlantic Ocean. Limnol Oceanogr 52:1287-1292. https://doi.org/10.4319/lo.2007.52.3.1287

Arístegui J, Barton ED, Álvarez-Salgado XA, Santos AMP, Figueiras FG, Kifani S, Hernández-León S, Mason E, Machú E, Demarcq $\mathrm{H}$ (2009) Sub-regional ecosystem variability in the Canary Current upwelling. Prog Oceanogr 83(1-4):33-48. https://doi.org/10. 1016/j.pocean.2009.07.031

Bakun A (1973) Coastal upwelling indices, West Coast of North America. 1946-71. US Department of Commerce, National Oceanic and Atmospheric Administration, National Marine Fisheries Service

Bakun A (1990) Global climate change and intensification of coastal ocean upwelling. Science 247:198-201. https://doi.org/10.1126/ science. 247.4939 .198

Bindoff NL, Cheung WWL, Kairo JG, Arístegui J, Guinder VA, Hallberg R, Hilmi N, Jiao N, Karim MS, Levin L, O’Donoghue S, Purca Cuicapusa SR, Rinkevich B, Suga T, Tagliabue A, Williamson $P$ (2019) Changing ocean, marine ecosystems, and dependent communities. In: Pörtner H-O, Roberts DC, Masson-Delmotte V, Zhai P, Tignor M, Poloczanska E, Mintenbeck K, Alegría A, Nicolai M, Okem A, Petzold J, Rama B, Weyer NM (eds.) IPCC special report on the ocean and cryosphere in a changing climate

Bonino G, Di Lorenzo E, Masina S, Iovino D (2019) Interannual to decadal variability within and across the major Eastern Boundary Upwelling Systems. Sci Rep 9:1-14. https://doi.org/10.1038/ s41598-019-56514-8

Boyer TP, Baranova OK, Coleman C, Garcia HE, Grodsky A, Locarnini RA, Mishonov AV, Paver CR, Reagan J, Seidov D, Smolyar IV, Weathers K, Zweng MM (2019) World Ocean Database 2018. AV Mishonov Technical Editor, NOAA Atlas NESDIS 87

Brady RX, Lovenduski NS, Alexander MA, Jacox M, Gruber N (2019) On the role of climate modes in modulating the air-sea co2 fluxes in eastern boundary upwelling systems. Biogeosciences 16:329 346. https://doi.org/10.5194/bg-16-329-2019

Brink KH (1983) The near-surface dynamics of coastal upwelling. Progr Oceanogr 2:223-257. https://doi.org/10.1016/00796611(83)90009-5

Bryan FO, Hecht MW, Smith RD (2007) Resolution convergence and sensitivity studies with North Atlantic circulation models. Part I: the western boundary current system. Ocean Model 16(3-4):141159. https://doi.org/10.1016/j.ocemod.2006.08.005

Cabos W, de la Vara A, Álvarez-García FJ, Sánchez E, Sieck K, PérezSanz JI, Limareva N, Sein DV (2020) Impact of ocean-atmosphere coupling on regional climate: the Iberian Peninsula case. Clim Dyn 54:4441-4467. https://doi.org/10.1007/s00382-020-05238-x

Carton JA, Chepurin GA, Chen L (2018) SODA3: a new ocean climate reanalysis. J Clim 31:6967-6983. https://doi.org/10.1175/ JCLI-D-18-0149.1

Chelton DB, deSzoeke RA, Schlax MG, El Naggar K, Siwertz N (1998) Geographical variability of the first baroclinic rossby radius of deformation. J Phys Ocean. https://doi.org/10.1175/ 1520-0485(1998)028\%3c0433:GVOTFB\%3e2.0.CO;2 
Christensen O, Drews M, Christensen J, Dethloff K, Ketelsen K, Hebestadt I, Rinke, A (2006) The HIRHAM Regional Climate Model, Version 5. http://www.dmi.dk/fileadmin/Rapporter/TR/ tr06-17.pdf

Copernicus Climate Change Service (C3S) (2017) ERA5: Fifth generation of ECMWF atmospheric reanalyses of the global climate. Copernicus Climate Change Service Climate Data Store (CDS), date of access. https://cds.climate.copernicus.eu/cdsapp\#!/home

Cropper TE, Hanna E, Bigg GR (2014) Spatial and temporal seasonal trends in coastal upwelling off Northwest Africa, 1981-2012. Deep Sea Res 86:94-111. https://doi.org/10.1016/j.dsr.2014.01. 007

Dee DP, Uppala SM, Simmons AJ, Berrisford P, Poli P, Kobayashi S, Andrae U, Balmaseda MA, Balsamo G, Bauer P, Bechtold P, Beljaars ACM, van den Berg L, Bidlot J, Bormann N, Delsol C, Dragani R, Fuentes M, Geer AJ, Haimberger L, Healy SB, Hersbach H, Hólm EV, Isaksen L, Kallber P, Kohler M, Matricardi M, McNally AP, Monge-Sanz BM, Morcrett JJ, Park BK, Peubey C, de Rosnay P, Tavolato C, Thépaut JN, Vitart F (2011) The ERA-Interim reanalysis: configuration and performance of the data assimilation system. Q J R Meteor Soc 137:553-597. https:// doi.org/10.1002/qj.828

Di Lorenzo E, Miller AJ, Schneider N, McWilliams JC (2005) The warming of the california current system: dynamics and ecosystem implications. J Phys Oceanogr 35:336-362. https://doi.org/ 10.1175/JPO-2690.1

Drévillon M, Regnier C, Lellouche JM, Garric G, Bricaud C, Hernandez O (2018) CMEMS-GLO-QUID-001-030, 1.2 edn. E.U. Copernicus Marine Service Information [Online]. https://resou rces.marine.copernicus.eu/documents/QUID/CMEMS-GLOQUID-001-030.pdf

Dufois F, Penven P, Whittle CP, Veitch J (2012) On the warm nearshore bias in Pathfinder monthly SST products over Eastern Boundary Upwelling Systems. Ocean Model 47:113-118. https://doi.org/10. 1016/j.ocemod.2012.01.007

Dufresne JL, Foujols MA, Denvil S, Caubel A, Marti O, Aumont O, Balkanski Y, Bekki S, Bellenger H, Benshila R, Bony S, Bopp L, Braconnot P, Brockmann P, Cadule P, Cheruy F, Codron F, Cozic A, Cugnet D, de Noblet N, Duvel JP, Ethé C, Fairhead L, Fichefet T, Flavoni S, Friedlingstein P, Grandpeix JY, Guez L, Guilyardi E, Hauglustaine D, Hourdin F, Idelkadi A, Ghattas J, Joussaume S, Kageyama M, Krinner G, Labetoulle S, Lahellec A, Lefebvre MP, Lefevre FM, Levy C, Li ZX, Lloyd J, Lott F, Madec G, Mancip M, Marchand M, Masson S, Meurdesoif Y, Mignot J, Musat I, Parouty S, Polcher J, Rio C, Schulz M, Swingedouw D, Szopa S, Talandier C, Terray P, Viovy N, Vuichard N (2013) Climate change projections using the IPSL-CM5 Earth System Model: from CMIP3 to CMIP5. Clim Dyn 40:2123-2165. https://doi.org/ 10.1007/s00382-012-1636-1

Eden C, Greatbatch RJ (2003) A damped decadal oscillation in the North Atlantic climate system. J Clim 16(24):4043-4060. https:// doi.org/10.1175/1520-0442(2003)0162.0.CO;2

Fischer G, Romero O, Toby E, Iversen M, Donner B, Mollenhauer G, Nowald N, Ruhland G, Klann M, Hamady B, Wefer G (2019) Changes in the dust-influenced biological carbon pump in the Canary Current System: implications from a coastal and an offshore sediment trap record off Cape Blanc, Mauritania. Global Biogeochem Cycles 33(8):1100-1128. https://doi.org/10.1029/ 2019GB006194

García-Muñoz M, Arístegui J, Pelegrí JL, Antoranz A, Ojeda A, Torres M (2005) Exchange of carbon by an upwelling filament off Cape Ghir (NW Africa). J Mar Syst 54(1-4):83-95. https://doi.org/10. 1016/j.jmarsys.2004.07.005

García-Reyes M, Sydeman WJ, Schoeman DS, Rykaczewski RR, Black BA, Smit AJ, Bograd SJ (2015) Under pressure: climate change, upwelling, and eastern boundary upwelling ecosystems. Front Mar Sci 2:109. https://doi.org/10.3389/fmars.2015.00109

Giorgetta MA, Jungclaus J, Reick CH, Legutke S, Bader J, Böttinger M, Brovkin V, Crueger T, Esch M, Fieg K, Glushak K, Gayler V, Haak H, Hollweg HD, Ilyina T, Kinne S, Kornblueh L, Matei D, Mauritsen T, Mikolajewicz U, Mueller W, Notz D, Pithan F, Raddatz T, Rast S, Redler R, Roeckner E, Schmidt H, Schnur R, Segschneider J, Six KD, Stockhause M, Timmreck C, Wegner J, Widmann H, Wieners KH, Claussen M, Marotzke J, Stevens B (2013) Climate and carbon cycle changes from 1850 to 2100 in MPI-ESM simulations for the Coupled Model Intercomparison Project phase 5. J Adv Model Earth Syst 5:572-597. https://doi. org/10.1002/jame.20038

Giorgi F, Coppola E, Solmon F, Mariotti L, Sylla MB, Bi X, Elguindi N, Diro GT, Nair V, Giuliani G, Cozzini S, Güttler I, O’Brien TA, Tawfik AB, Shalaby A, Zakey AS, Steiner AL, Stordal F, Sloan LC, Brankovic C (2012) RegCM4: model description and preliminary tests over multiple CORDEX domains. Clim Res 52:7-29

Gomez-Gesteira M, Moreira C, Alvarez I, Decastro M (2006) Ekman transport along the Galician coast (northwest Spain) calculated from forecasted winds. J Geophys Res. https://doi.org/10.1029/ $2005 \mathrm{jc} 003331$

Gómez-Letona M, Ramos AG, Coca J, Arístegui J (2017) Trends in primary production in the Canary Current upwelling system a regional perspective comparing remote sensing models. Front Mar Sci 4:370. https://doi.org/10.3389/fmars.2017.00370

Good SA, Embury O, Bulgin CE, Mittaz J (2019) ESA Sea Surface Temperature Climate Change Initiative (SST_cci): Level 4 Analysis Climate Data Record, version 2.0. Centre for Environmental Data Analysis, 22 August 2019. https://doi.org/10.5285/aced4 0d7cb964f23a0fd3e85772f2d48

Gruber N, Lachkar Z, Frenzel H, Marchesiello P, Münnich M, McWilliams JC, Nagai T, Plattner GK (2011) Eddy-induced reduction of biological production in eastern boundary upwelling systems. Nature Geosci 4(11):787-792. https://doi.org/10.1038/ngeo1273

Hagemann S, Dumenil-Gates L (1998) A parameterization of the lateral waterflow for the global scale. Clim Dyn 14:17-31. https:// doi.org/10.1007/s003820050205

Hagemann S, Dumenil-Gates L (2001) Validation of the hydrological cycle of ECMWF and NCEP reanalysis using the MPI hydrological discharge model. J Geophys Res 106(D2):1503-1510. https:// doi.org/10.1029/2000JD900568

Hagen E, Zülicke C, Feistel R (1996) Near-surface structures in the Cape Ghir filament off Morocco. Oceanol Acta 19:577-598. https://archimer.ifremer.fr/doc/00096/20728/

Hall DK, Riggs GA (2007) Accuracy assessment of the MODIS snowcover products. Hydrol Process 21:1534-1547. https://doi.org/10. 1002/hyp.6715

Hazeleger W, Severijns C, Semmler T et al (2010) EC-earth: a seamless earth-system prediction approach in action. Bull Am Meteorol Soc 91:1357-1364. https://doi.org/10.1175/2010BAMS2877.1

Izquierdo A, Mikolajewicz U (2019) The role of tides in the spreading of Mediterranean Outflow waters along the southwestern Iberian margin. Ocean Model 133:27-43. https://doi.org/10.1016/j. ocemod.2018.08.003

Jacob D (2001) A note to the simulation of the annual and interannual variability of the water budget over the Baltic Sea drainage basin. Meteorol Atmos Phys 77(1-4):61-73. https://doi.org/10.1007/ s007030170017

Jones RG, Noguer M, Hassell DC, Hudson D, Wilson SS, Jenkins GJ, Mitchell JFB (2004) Generating high resolution climate change change scenarios using PRECIS. Met Office Hadley Centre, Exeter

Jones CD, Hughes JK, Bellouin N, Hardiman SC, Jones GS, Knight J, Liddicoat S, O’Connor FM, Andres RJ, Bell C, Boo K-O, Bozzo 
A, Butchart N, Cadule P, Corbin KD, Doutriaux-Boucher M, Friedlingstein P, Gornall J, Gray L, Halloran PR, Hurtt G, Ingram WJ, Lamarque J-F, Law RM, Meinshausen M, Osprey S, Palin EJ, Parsons Chini L, Raddatz T, Sanderson MG, Sellar AA, Schurer A, Valdes P, Wood N, Woodward S, Yoshioka M, Zerroukat M (2011) The HadGEM2-ES implementation of CMIP5 centennial simulations. Geosci Model Dev 4:543-570. https://doi.org/10. 5194/gmd-4-543-2011

Jungclaus JH, Fischer N, Haak H, Lohmann K, Marotzke J, Matei D, Mikolajewicz U, Notz D, von Storch JS (2013) Characteristics of the ocean simulations in MPIOM, the ocean component of the MPI-Earth system model. J Adv Model Earth Syst 5:422-446. https://doi.org/10.1002/jame.20023

Kämpf J, Chapman P (2016) The canary/Iberia current upwelling system. In: Upwelling Systems of the World, pp 203-250. https://doi. org/10.1007/978-3-319-42524-5_6

Levitus S, Boyer TP, Conkright ME, O’Brien T, Antonov J, Stephens C, Stathoplos L, Johnson D, Gelfeld, R (1998) World Ocean Database 1998, vol.1, Introduction, NOAA Atlas NESDIS 18, Ocean Clim. Lab., Natl. Oceanogr. Data Cent., U.S. Gov. Print. Off., Washington, D.C.

Li H, Kanamitsu M, Hong SY (2012) California reanalysis downscaling at $10 \mathrm{~km}$ using an ocean-atmosphere coupled regional model system. J Geophys Res 117:D12118. https://doi.org/10.1029/2011J D017372

Lovecchio E, Gruber N, Münnich M, Lachkar Z (2017) On the longrange offshore transport of organic carbon from the Canary Upwelling System to the open North Atlantic. Biogeosciences 14(13):3337-3369. https://doi.org/10.3929/ethz-b-000190480

Lovecchio E, Gruber N, Münnich M (2018) Mesoscale contribution to the long-range offshore transport of organic carbon from the Canary Upwelling System to the open North Atlantic. Biogeosciences 15:5061-5091. https://doi.org/10.5194/bg-15-5061-2018

Maier-Reimer E, Kriest I, Segschneider J, Wetzel P (2005) The HAMburg Ocean Carbon Cycle Model HAMOCC5.1 Technical Description Release 1.1, Ber. Erdsystemforschung, 14, http://hdl. handle.net/11858/00-001M-0000-0011-FF5C-D

Marsland SJ, Haak H, Jungclaus JH, Latif M, Roeske F (2003) The Max-Planck-Institute global ocean/sea icemodel with orthogonal curvilinear coordinates. Ocean Model 5(2):91-127. https://doi. org/10.1016/S1463-5003(02)00015-X

Mason E, Colas F, Molemaker J, Shchepetkin AF, Troupin C, McWilliams JC, Sangrà P (2011) Seasonal variability of the Canary current: a numerical study. J Geophys Res Oceans 116(6):1-20. https://doi.org/10.1029/2010JC006665

Menna M, Faye S, Poulain PM, Centurioni L, Lazar A, Gaye A, Sow B, Dagorne D (2016) Upwelling features off the coast of northwestern Africa in 2009-2013. Bollettino Di Geofisica Teorica Ed Applicata 57:71-86. https://doi.org/10.4430/bgta0164

Merchant CJ, Embury O, Bulgin CE, Block T, Corlett G, Fiedler E, Good SA, Mittaz J, Rayner N, Berry D, Eastwood S (2019) Satellite-based time-series of sea-surface temperature since 1981 for climate applications. Nat Sci Data 6:223. https://doi.org/10.1038/ s41597-019-0236-x

Mikolajewicz U, Sein DV, Jacob D, Königk T, Podzun R, Semmler $T$ (2005) Simulating Arctic sea ice variability with a coupled regional atmosphere-ocean-sea ice model. Meteorol Zeitschrift 14(6):793-800. http://hdl.handle.net/11858/ 00-001M-0000-0011-FF70-E

Ning H, Li-Juan L, Bin W (2014) The role of the aerosol indirect effect in the northern Indian Ocean warming simulated by CMIP5 models. Atmos Oceanic Sci Lett 7:411-416. https://doi.org/10.1080/ 16742834.2014.11447199
Oyarzún D, Brierley CM (2018) The future of coastal upwelling in the Humboldt current from model projections. Clim Dyn 52:599-615. https://doi.org/10.1007/s00382-018-4158-7

Pardo PC, Padín XA, Gilcoto M, Farina-Busto L, Pérez FF (2011) Evolution of upwelling systems coupled to the long-term variability in sea surface temperature and Ekman transport. Clim Res 48(2-3):231-246. https://doi.org/10.3354/cr00989

Parras-Berrocal I, Vazquez R, Cabos W, Sein D, Mañanes R, PerezSanz J, Izquierdo A (2020) The climate change signal in the Mediterranean Sea in a regionally coupled ocean-atmosphere model. Ocean Sci 16:743-765. https://doi.org/10.5194/os-16-743-2020

Pauly D, Christensen V (1995) Primary production required to sustain global fisheries. Nature 374:255-257

Pelegrí JL, Benazzouz A (2015) Coastal upwelling off North-West Africa. In: Valdés L, Déniz-González I (eds) Oceanographic and biological features in the Canary Current Large Marine Ecosystem. IOC-UNESCO, Paris. IOC Technical Series, No. 115:383

Pelegrí JL, Aristegui J, Cana L, González-Dávila M, Hernández-Guerra A, Hernández-León S, Marrero-Díaz A, Montero MF, Sangrá P, Santana-Casiano M (2005) Coupling between the open ocean and the coastal upwelling region off northwest Africa: water recirculation and offshore pumping of organic matter. J Mar Syst 54:3-37. https://doi.org/10.1016/j.jmarsys.2004.07.003

Pelegri JL, Marrero-Diaz A, Ratsimandresy AW (2006) Nutrient irrigation of the North Atlantic. Prog Oceanogr 70:366-406. https://doi. org/10.1016/j.pocean.2006.03.018

Relvas P, Luis J, Santos AMP (2009) Importance of the mesoscale in the decadal changes observed in the northern Canary upwelling system. Geophys Res Lett. https://doi.org/10.1029/2009GL0405 04

Renault L, Deutsch C, McWilliams JC, Frenzel H, Liang JH, Colas F (2016) Partial decoupling of primary productivity from upwelling in the California current system. Nat Geosci 9(7):505-508. https:// doi.org/10.1038/ngeo2722

Reynolds RW, Smith TM, Liu C, Chelton DB, Casey KS, Schlax MG (2007) Daily High-Resolution-Blended Analyses for sea surface temperature. J Climate 20(22):5473-5496. https://doi.org/10. 1175/2007JCLI1824.1

Rockel B, Will A, Hense A (2008) The regional climate model COSMO-CLM (CCLM). Meteorol Z 17(4):347-348. https://doi. org/10.1127/0941-2948/2008/0309

Roxy M, Ritika K, Terray P, Murtugudde R, Ashok K, Goswami BN (2015) Drying of Indian subcontinent by rapid Indian Ocean warming and a weakening land-sea thermal gradient. Nat Commun 6:7423. https://doi.org/10.1038/ncomms8423

Rykaczewski RR, Dunne JP, Sydeman WJ, Garcia-Reyes M, Black BA, Bograd SJ (2015) Poleward displacement of coastal upwellingfavorable winds in the ocean's eastern boundary currents through the 21st century. Geophys Res Lett 42:6424-6431. https://doi.org/ 10.1002/2015GL064694

Samuelsson P, Gollvik S, Jansson C, Kupiainen M, Kourzeneva E, van de Berg WJ (2015) The surface processes of the Rossby Centre regional atmospheric climate model (RCA4). SMHI Rep 157:58

Sangrá P (2015) Canary Islands eddies and coastal upwelling filaments off North-west Africa. In: Valdés, L, Déniz-González I (eds) Oceanographic and biological features in the Canary Current Large Marine Ecosystem. IOC-UNESCO, Paris. IOC Technical Series, No. 115, pp 105-114. http://hdl.handle.net/1834/9181.

Sangrá P, Troupin C, Barreiro-González B, Desmond Barton E, Orbi A, Arístegui J (2015) The Cape Ghir filament system in August 2009 (NW Africa). J Geophys Res Oceans 120:4516-4533. https://doi. org/10.1002/2014JC010514

Santana-Falcón Y, Benavides M, Sangrà P, Mason E, Barton ED, Orbi A, Arístegui J (2016) Coastal-offshore exchange of organic matter across the Cape Ghir filament (NW Africa) during moderate 
upwelling. J Mar Syst 154:233-242. https://doi.org/10.1016/j. jmarsys.2015.10.008

Santana-Falcón Y, Mason E, Arístegui J (2020) Offshore transport of organic carbon by upwelling filaments in the Canary Current System. Prog Oceanogr 184(April):102322. https://doi.org/10.1016/j. pocean.2020.102322

Sein DV, Mikolajewicz U, Gröger M, Fast I, Cabos W, Pinto JG, Hagemann S, Semmler T, Izquierdo A, Jacob D (2015) Regionally coupled atmosphere-ocean-sea ice-marine biogeochemistry model ROM: 1. Description and validation. J Adv Model Earth Syst 7:268-304. https://doi.org/10.1002/2014MS000357

Sein DV, Koldunov NV, Danilov S, Wang Q, Sidorenko D, Fast I, Rackow T, Cabos W, Jung T (2017) Ocean modeling on a mesh with resolution following the local rossby radius. J Adv Model Earth Syst 9:2601-2614. https://doi.org/10.1002/2017MS001099

Sein DV, Gröger M, Cabos W, Alvarez-Garcia FJ, Hagemann S, Pinto JG, Izquierdo I, de la vara A, Koldunov NV, Dvornikov AY, Limareva N, Aleekseva E, Martinez-Lopez B, Jacob D (2020) Regionally coupled atmosphere-ocean-marine biogeochemistry model ROM: 2. Studying the climate change signal in the North Atlantic and Europe. J Adv Model Earth Syst. https://onlinelibrary.wiley. com/doi/abs/10.1029/2019MS001646

Soares PMM, Lima DCA, Semedo A, Cardoso RM, Cabos W, Sein DV (2018) Assessing the climate change impact on the North African offshore surface wind and coastal low-level jet using coupled and uncoupled regional climate simulations. Clim Dyn. https://doi. org/10.1007/s00382-018-4565-9

Soares PM, Lima DC, Semedo A, Cabos Narvaez WD, Sein D (2019) Climate change impact on the Northwestern African offshore wind energy resources. Environ Res Lett. https://doi.org/10.1088/ 1748-9326/ab5731

Sousa MC, de Castro M, Álvarez I, Gomez-Gesteira M, Dias JM (2017a) Why coastal upwelling is expected to increase along the Western Iberian Peninsula over the next century? Sci Total Environ 592:243-251. https://doi.org/10.1016/j.scitotenv.2017.03.046

Sousa MC, Alvarez I, deCastro M, Gomez-Gesteira M, Dias JM (2017b) Seasonality of coastal upwelling trends under future warming scenarios along the southern limit of the Canary upwelling system. Prog Oceanogr 153:16-23. https://doi.org/10. 1016/j.pocean.2017.04.002

Sydeman WJ, Garcia-Reyes M, Schoeman DS, Rykaczewski RR, Thompson SA, Black BA, Bograd SJ (2014) Climate change and wind intensification in coastal upwelling ecosystems. Science 345:77-80. https://doi.org/10.1126/science.1251635

Sylla A, Mignot J, Capet X, Gaye AT (2019) Weakening of the Senegalo-Mauritanian upwelling system under climate change. Clim Dyn 53(7-8):4447-4473. https://doi.org/10.1007/ s00382-019-04797-y

Takhsha M, Nikiéma O, Lucas-Picher P, Laprise R, HernándezDíaz L, Winger K (2017) Dynamical downscaling with the fifth-generation Canadian regional climate model (CRCM5) over the CORDEX Arctic domain: effect of large-scale spectral nudging and of empirical correction of sea-surface temperature. Clim Dyn. https://doi.org/10.1007/s00382-017-3912-6

Troupin C, Mason E, Beckers JM (2012) Sangrà P (2012) Generation of the Cape Ghir upwelling filament: a numerical study. Ocean Model 41:1-15

Valcke S (2013) The OASIS3 coupler: a European climate modelling community software. Geosci Model Dev 6:373-388. https://doi. org/10.5194/gmd-6-373-2013

van Meijgaard E, van Ulft LH, van den Berg WJ, Bosveld FC, van den Hurk BJJM, Lenderink G, Siebesma AP (2008) The KNMI regional atmospheric climate model RACMO version 2.1. KNMI Tech. Rep. TR-302, 43

Varela R, Alvarez I, Santos F, deCastro M, Gomez-Gesteira M (2015) Has upwelling strengthened along worldwide coasts over 19822010? Sci Rep. https://doi.org/10.1038/srep10016

Voldoire A, Sanchez-Gomez E, Salas y Mélia D, Decharme B, Cassou C, Sénési S, Valcke S, Beau I, Alias A, Chevallier M, Déqué M, Deshayes J, Douville H, Fernandez E, Madec G, Maisonnave E, Moine M-P, Planton S, Saint-Martin D, Szopa S, Tyteca S, Alkama R, Belamari S, Braun A, Coquart L, Chauvin F (2013) The CNRM-CM5.1 global climate model: description and basic evaluation. Clim Dyn 40:2091-2121. https://doi.org/10.1007/ s00382-011-1259-y

Wang DW, Gouhier TC, Menge BA, Ganguly AR (2015) Intensification and spatial omogenization of coastal upwelling under climate change. Nature. https://doi.org/10.1038/nature14235

Ward ND, Megonigal JP, Bond-Lamberty B, Bailey VL, Butman D, Canuel EA, Diefenderfer H, Ganju NK, Goñi MA, Graham EB, Hopkinson CS, Khangaonkar T, Langley JA, McDowell NG, Myers-Pigg AN, Neumann RB, Osburn CL, Price RM, Rowlnad J, Sengupta A, Simard M, Thornton PE, Tzortziou M, Vargas R, Weisenhorn PB, Hopkinson CS (2020) Representing the function and sensitivity of coastal interfaces in Earth system models. Nat Commun 11:2458. https://doi.org/10.1038/s41467-020-16236-2

Wooster WS, Bakun A, McLain D (1976) The seasonal upwelling cycle along the eastern boundary of the North Atlantic. J Mar Res 34(2):131-141

Xiu P, Chai F, Curchitser E, Castruccio F (2018) Future changes in coastal upwelling ecosystems with global warming: the case of the California Current System. Sci Rep 8:2866. https://doi.org/10. 1038/s41598-018-21247-7

Publisher's Note Springer Nature remains neutral with regard to jurisdictional claims in published maps and institutional affiliations. 